\title{
Inhibitory protection of steels in acid solutions under high- temperature corrosion conditions. A review. Part 3
}

\author{
Ya.G. Avdeev*iD and Yu.I. Kuznetsov \\ A.N. Frumkin Institute of Physical Chemistry and Electrochemistry, Russian Academy of \\ Sciences, Leninsky pr. 31, 119071 Moscow, Russian Federation \\ *E-mail: avdeevavdeev@mail.ru
}

\begin{abstract}
Literature data concerning the protection of steels in acid solutions at elevated temperatures $\left(t \leq 200^{\circ} \mathrm{C}\right)$ by organic nitrogen-containing heterocyclic compounds (NHCs) and formulations based on them are generalized. It is noted that individual NHCs are rarely efficient in steel protection in acid solutions at $t>100^{\circ} \mathrm{C}$. However, composite inhibitors based on some of these compounds allows their protective effect to be expanded to $t=200^{\circ} \mathrm{C}$ in certain cases. Data on the protection of various steels by composite inhibitors of this kind is discussed. The most outstanding results in the protection of low-carbon and chromium-nickel steels in hightemperature acid solutions are provided by formulations based on triazole derivatives, which effectively inhibit corrosion in mineral $\left(\mathrm{HCl}, \mathrm{H}_{2} \mathrm{SO}_{4}, \mathrm{H}_{3} \mathrm{PO}_{4}\right)$ and organic (acetic, formic, citric) acids. Problems related to the mechanism of the inhibitory effect of triazoles are discussed. It is shown that the possibility of providing steel protection at these high temperatures is due to the unique mechanism of the inhibitory action of triazoles that are chemisorbed on the metal surface and form a monomolecular layer strongly bound to the surface. Additional physical or chemical polymolecular adsorption of inhibitor molecules occurs on top of that layer, which significantly improves its protective properties. Generalization of data on the inhibitory protection of steels in high-temperature acid solutions with unsaturated organic compounds and NHCs, as well as an analysis of the mechanism of their action made it possible to formulate modern approaches to the creation of high-temperature inhibitors for acid solutions. The bibliography includes 137 sources.
\end{abstract}

Keywords: high-temperature acid corrosion, steel, corrosion inhibitors, acidizing, hydrochloric acid, sulfuric acid, phosphoric acid, acetic acid, formic acid, citric acid, nitrogen-containing heterocyclic compounds, triazole, diazole, tetrazole.

Received: July 27, 2020. Published: October 6, 2020

doi: $\underline{10.17675 / 2305-6894-2020-9-4-3}$

\section{Introduction}

In the final part of our review we consider the most significant results achieved over the past decades in the field of inhibitory protection of steels in high-temperature acid solutions $\left(t \geq 80^{\circ} \mathrm{C}\right)$ and related to studies of various azoles as corrosion inhibitors of steels in acid media. The preceding part of the review [1] generalizes the literature data on the protection of steels in acid solutions by unsaturated organic compounds (UCs) and formulations based 
on them at temperatures $t \leq 250^{\circ} \mathrm{C}$. It was noted that UCs themselves, i.e., acetylenic compounds (ACs), unsaturated aldehydes, ketones and azomethines, are rarely efficient for steel protection in $\mathrm{HCl}$ solutions at $t>100^{\circ} \mathrm{C}$. The creation of a mixed corrosion inhibitors (CIs) based on some of them sometimes makes it possible to expand the range of their protective action to $t=250^{\circ} \mathrm{C}$.

Data on the protection of various steels by such CIs was discussed. It was noted that such CIs are most suitable for corrosive high-temperature $\mathrm{HCl}$ solutions. Issues related to the mechanism of the inhibitory effect of UCs were discussed. It was shown that the possibility of steel protection at these high $t$ is a consequence of the inhibition mechanism of UCs that results from their ability to be chemisorbed on a metal surface and undergo deep chemical transformations to form a protective polymer film. This often leads to the formation of a protective polymer film. The factors that limit the use of formulations containing UCs were analyzed, including their instability in hot corrosive media over time and polymerization in the acid bulk that removes the inhibitor from the corrosive environment. Moreover, the UCs themselves and the additives used in combination with them are very toxic compounds.

In this review, nitrogen-containing heterocyclic organic compounds (NHCs) mainly represented by azoles will be considered as high-temperature CIs (HCIs). These compounds are, to a considerable extent, devoid of the drawbacks inherent in UCs in the protection of steels in mineral acid solutions. Not only the effect of NHCs on the corrosion process but also the possibility of improving their protective effect by creating mixed CIs on their basis will be considered. The analysis of modern concepts concerning the mechanism of metal protection by NHCs is important for the development of a scientific approach to the use of these compounds and creation of formulations based thereon.

Reference information on the possibility of using individual NHCs to protect steels from degradation in acid solutions in the oil and gas industry is given in recent reviews [24], but this information is limited to $t=110^{\circ} \mathrm{C}$. So it does not fully meet the needs of modern production and does not reliably reflect the capabilities of this group of CIs which, in some cases, can efficiently slow down the corrosion of metals at $t \leq 200^{\circ} \mathrm{C}$.

The general issues of steel protection in acid solutions by NHCs were considered in review articles $[5,6]$. Some specific features of the mechanism of their inhibitory action are also discussed there. In this review, priority is given to the generalization and analysis of issues related to the use of these CIs against the high-temperature corrosion of steels.

The group of HCIs that protect chromium-nickel steels in phosphoric acid solutions is narrow and they have a specific mechanism of action. It is represented by inorganic compounds that will also be briefly covered in our review.

In the first part of this review [7], we discussed the methodological and technical specifics of studying the corrosion of steels and their electrochemical behavior in acid solutions at elevated temperatures, both in the absence and in the presence of CIs. The chemical composition of steels discussed in this review is given in Table 1. 
Table 1. Chemical composition of steels.

Steel brand

\begin{tabular}{|c|c|}
\hline Steel 3 & $\begin{array}{l}0.14-0.22 \mathrm{C} \text {; } 0.15-0.33 \mathrm{Si} ; 0.40-0.65 \mathrm{Mn} \text {; up to } 0.3 \mathrm{Cr} \text {; up to } 0.30 \mathrm{Ni} \text {; up to } \\
0.008 \mathrm{~N} \text {; up to } 0.30 \mathrm{Cu} \text {; up to } 0.05 \mathrm{~S} \text {; up to } 0.04 \mathrm{P} \text {; up to } 0.08 \mathrm{As} \text {; remainder } \mathrm{Fe}\end{array}$ \\
\hline Steel 5 & $0.28-0.37 \mathrm{C}$; up to $0.3 \mathrm{Si} ; 0.5-0.8 \mathrm{Mn}$; up to $0.05 \mathrm{~S}$; up to $0.04 \mathrm{P}$; remainder $\mathrm{Fe}$ \\
\hline Steel 10 & $\begin{array}{l}0.07-0.14 \mathrm{C} ; 0.17-0.37 \mathrm{Si} ; 0.35-0.65 \mathrm{Mn} \text {; up to } 0.15 \mathrm{Cr} \text {; up to } 0.25 \mathrm{Ni} \text {; up to } \\
0.25 \mathrm{Cu} \text {; up to } 0.04 \mathrm{~S} \text {; up to } 0.035 \mathrm{P} \text {; up to } 0.08 \mathrm{As} \text {; remainder } \mathrm{Fe}\end{array}$ \\
\hline Steel 20 & $\begin{array}{l}0.17-0.24 \mathrm{C} ; 0.17-0.37 \mathrm{Si} ; 0.35-0.65 \mathrm{Mn} \text {; up to } 0.25 \mathrm{Cr} \text {; up to } 0.30 \mathrm{Ni} \text {; up to } \\
0.30 \mathrm{Cu} \text {; up to } 0.04 \mathrm{~S} \text {; up to } 0.035 \mathrm{P} \text {; up to } 0.08 \mathrm{As} \text {; remainder } \mathrm{Fe}\end{array}$ \\
\hline Steel 45 & $\begin{array}{l}0.42-0.50 \mathrm{C} ; 0.17-0.37 \mathrm{Si} ; 0.5-0.8 \mathrm{Mn} \text {; up to } 0.25 \mathrm{Cr} \text {; up to } 0.25 \mathrm{Ni} \text {; up to } 0.25 \mathrm{Cu} \text {; } \\
\text { up to } 0.04 \mathrm{~S} \text {; up to } 0.035 \mathrm{P} \text {; up to } 0,08 \mathrm{As} \text {; remainder } \mathrm{Fe}\end{array}$ \\
\hline Steel D & $\begin{array}{c}0.41-0.48 \mathrm{C} ; 0.17-0.37 \mathrm{Si} ; 0.65-0.90 \mathrm{Mn} ; \text { up to } 0.045 \mathrm{~S} ; 0.045 \mathrm{P} ; 0.25 \mathrm{Cu} \text {; } \\
\text { remainder } \mathrm{Fe}\end{array}$ \\
\hline $\begin{array}{l}\text { Mild steel [18- } \\
\quad 21,39,40]\end{array}$ & 0.14 C; 0.35 Mn; 0.17 Si; 0.025 S; 0.03 P; remainder Fe \\
\hline Mild steel [86] & $0.13 \mathrm{C} ; 0.39 \mathrm{Mn} ; 0.18 \mathrm{Si} ; 0.04 \mathrm{~S} ; 0.40 \mathrm{P} ; 0,025 \mathrm{Cu}$; remainder Fe \\
\hline $\begin{array}{l}\text { Carbon steel } \\
{[76]}\end{array}$ & $0.18 \mathrm{C} ; 0.25 \mathrm{Si} ; 0.42 \mathrm{Mn} ; 0.18 \mathrm{Cr} ; 0.22 \mathrm{Ni} ; 0.21 \mathrm{Cu} ; 0.02 \mathrm{~S} ; 0.02 \mathrm{P}$; remainder $\mathrm{Fe}$ \\
\hline $\begin{array}{l}\text { Cold rolled } \\
\text { steel [77] }\end{array}$ & 0.07 C; 0.3 Mn; 0.022 P; 0.010 S; 0.01 Si; 0.030 Al; remainder Fe \\
\hline N80 & $\begin{array}{l}0.34-0.38 \mathrm{C} ; 0.20-0.35 \mathrm{Si} ; 1.45-1.7 \mathrm{Mn} \text {; up to } 0.02 \mathrm{P} \text {; up to } 0.015 \mathrm{~S} \text {; up to } 0.15 \mathrm{Cr} \text {; } \\
0.11-0.16 \mathrm{~V} \text {; remainder Fe }\end{array}$ \\
\hline P110 & $\begin{array}{l}0.26-0.395 \mathrm{C} ; 0.17-0.37 \mathrm{Si} ; 0.40-0.70 \mathrm{Mn} \text {; up to } 0.020 \mathrm{P} \text {; up to } 0.010 \mathrm{~S} ; 0.80- \\
1.10 \mathrm{Cr} \text {; up to } 0.20 \mathrm{Ni} \text {; up to } 0.20 \mathrm{Cu} ; 0.15-0.25 \mathrm{Mo} \text {; up to } 0.08 \mathrm{~V} \text {; remainder } \mathrm{Fe}\end{array}$ \\
\hline $\mathrm{X} 80$ & $\begin{array}{c}0.064 \mathrm{C} ; 0.025 \mathrm{Si} ; 1.56 \mathrm{Mn} ; 0.013 \mathrm{P} ; 0.004 \mathrm{~S} ; 0.01 \mathrm{Cu} ; 0.021 \mathrm{Cr} ; 0.056 \mathrm{Nb} ; 0.005 \mathrm{~V} \text {; } \\
0.025 \mathrm{Ti} ; 0.0006 \mathrm{~B} \text {; remainder Fe }\end{array}$ \\
\hline
\end{tabular}

\begin{tabular}{|c|c|}
\hline Kh18N9T & $0.11 \mathrm{C} ; 9.66 \mathrm{Ni} ; 18.66 \mathrm{Cr} ; 0.57 \mathrm{Ti}$; remainder Fe \\
\hline 1Kh18N9T & 17.57 Cr; $9.16 \mathrm{Ni} ; 71.92 \mathrm{Fe} ; 0.83 \mathrm{Ti} ; 0.52 \mathrm{Si}$ \\
\hline 08Kh18N10T & $\begin{array}{l}0.08 \mathrm{C} \text {; } 0.8 \mathrm{Si} \text {; up to } 2 \mathrm{Mn} ; 9-11 \mathrm{Ni} \text {; up to } 0.02 \mathrm{~S} \text {; up to } 0.035 \mathrm{P} ; 17-19 \mathrm{Cr} \text {; up to } \\
\qquad 0.3 \mathrm{Cu} \text {; up to } 0.7 \mathrm{Ti} \text {; remainder } \mathrm{Fe}\end{array}$ \\
\hline 12Kh18N10T & $\begin{array}{l}\text { up to } 0.12 \mathrm{C} \text {; up to } 0.8 \mathrm{Si} \text {; up to } 2 \mathrm{Mn} ; 9-11 \mathrm{Ni} \text {; up to } 0.02 \mathrm{~S} \text {; up to } 0.035 \mathrm{P} \text {; } \\
\qquad 17-19 \mathrm{Cr} \text {; up to } 0.3 \mathrm{Cu} \text {; up to } 0.5 \mathrm{Ti} \text {; remainder } \mathrm{Fe}\end{array}$ \\
\hline Kh17N13M2T & $\begin{array}{l}\text { up to } 0.1 \mathrm{C} \text {; up to } 0.8 \mathrm{Si} \text {; up to } 2 \mathrm{Mn} \text {; up to } 0.035 \mathrm{P} \text {; up to } 0.02 \mathrm{~S} ; 16-18 \mathrm{Cr} \text {; } \\
\qquad 12-14 \mathrm{Ni} \text {; up to } 0.3 \mathrm{Cu} ; 2-3 \mathrm{Mo} \text {; up to } 0.7 \mathrm{Ti} \text {; remainder } \mathrm{Fe}\end{array}$ \\
\hline Kh17N13M3T & $\begin{array}{l}\text { up to } 0.1 \mathrm{C} \text {; up to } 0.8 \mathrm{Si} \text {; up to } 2.0 \mathrm{Mn} \text {; up to } 0.035 \mathrm{P} \text {; up to } 0.02 \mathrm{~S} ; 16-18 \mathrm{Cr} ; 12-14 \\
\mathrm{Ni} \text {; up to } 0.3 \mathrm{Cu} ; 3-4 \mathrm{Mo} \text {; up to } 0.7 \mathrm{Ti} \text {; remainder } \mathrm{Fe}\end{array}$ \\
\hline
\end{tabular}




\section{Protection of steels in acid solutions by nitrogen-containing heterocyclic organic compounds}

The first studies of NHCs as HCIs of steels in $\mathrm{HCl}$ solutions were carried out in the $1960 \mathrm{~s}$ and dealt with pyridine derivatives [8]. It was shown that in the protection of steel 5 in $16 \%$ $\mathrm{HCl}$ (300 atm) by addition of $0.5 \%$ catapin A ( $p$-alkylbenzylpyridinium chloride $\left[\mathrm{H}_{3} \mathrm{C}\left(\mathrm{CH}_{2}\right)_{n} \mathrm{CH}_{2} \mathrm{C}_{6} \mathrm{H}_{4} \mathrm{CH}_{2} \mathrm{NC}_{5} \mathrm{H}_{5}\right] \mathrm{Cl}$, where $\left.n=8-10\right)$, with an increase in the acid temperature the corrosion inhibition coefficient passes through a maximum at $65^{\circ} \mathrm{C}$ (Figure 1). Under the same conditions, a mixture of polyalkylpyridines (I-1-A inhibitor, 1\%) is characterized by a higher temperature of the maximum inhibitor efficiency toward steel 5 . In individual form, both CIs turned out to be poorly efficient in steel protection at $t>100^{\circ} \mathrm{C}$. However, their mixtures with urotropine satisfactorily inhibit metal corrosion at $t \leq 110^{\circ} \mathrm{C}$, though urotropine itself is inefficient under these conditions. The strongest protective effect is provided by the three-component formulation $0.4 \% \mathrm{I}-1-\mathrm{A}+0.8 \%$ urotropine $+1 \% \mathrm{Na}_{2} \mathrm{SO}_{4}$ that protects steel 5 up to $t=130^{\circ} \mathrm{C}$, but no detailed information about its properties is reported in the article. A drawback of catapin A as a corrosion inhibitor noted in the article is that it undergoes decomposition due to hydrolysis in the acid solution.

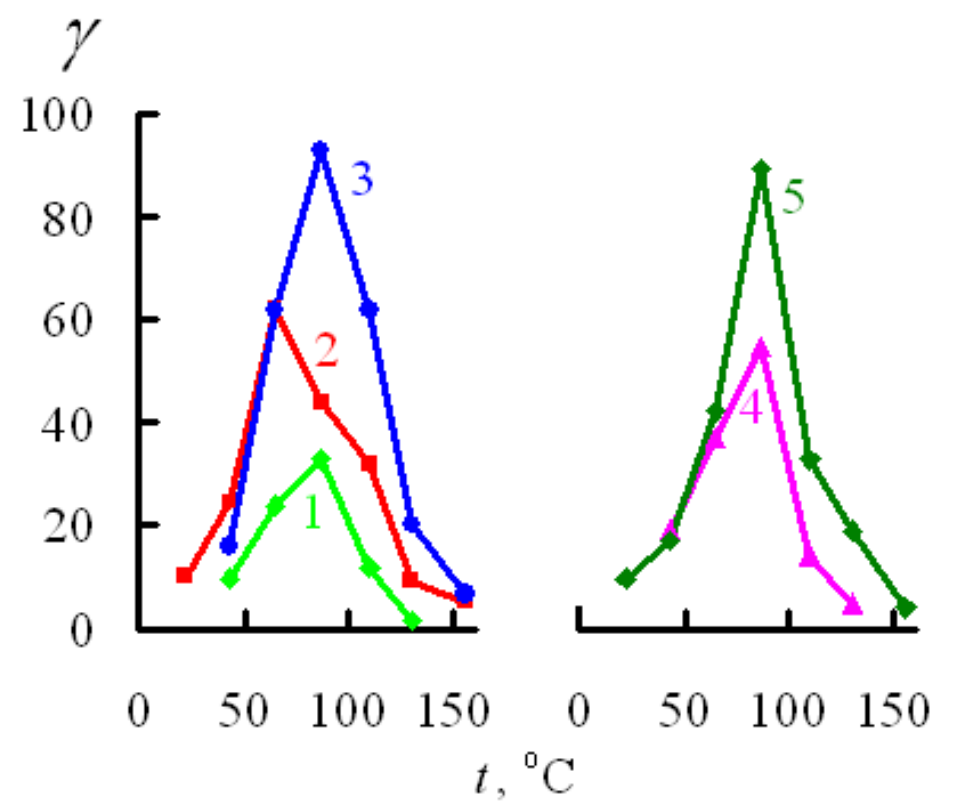

Figure 1. Steel corrosion inhibition factors for steel 5 in $16 \% \mathrm{HCl}(300 \mathrm{~atm})$ with addition of $1 \%$ urotropine (1), $0.5 \%$ catapin A (2), $0.5 \%$ catapin A $+0.5 \%$ urotropine (3), $1 \%$ I-1-A (4), $0.4 \% \mathrm{I}-1-\mathrm{A}+0.8 \%$ urotropine (5).

Various pyridine derivatives protect steel 10 in $15 \% \mathrm{HCl}\left(25-100^{\circ} \mathrm{C}\right)$ where the corrosion rate in the background solution is $k_{0}=5.7-2860 \mathrm{~g} /\left(\mathrm{m}^{2} \cdot \mathrm{h}\right)$ [9]. In the presence of $0.5 \%$ catapin $\mathrm{K}$ ( $p$-alkylbenzylpyridinium chloride $\left[\mathrm{H}_{3} \mathrm{C}\left(\mathrm{CH}_{2}\right)_{n} \mathrm{CH}_{2} \mathrm{C}_{6} \mathrm{H}_{4} \mathrm{CH}_{2} \mathrm{NC}_{5} \mathrm{H}_{5}\right] \mathrm{Cl}$, where $n=4-6)$, the corrosion rate of steel is $k \leq 5.1 \mathrm{~g} /\left(\mathrm{m}^{2} \cdot \mathrm{h}\right)$. This parameter is worse in the case of the I-1-A inhibitor, $k \leq 6.3 \mathrm{~g} /\left(\mathrm{m}^{2} \cdot \mathrm{h}\right)$. It is interesting that $0.5 \%$ catapin $\mathrm{K}$ effectively 
slows down the corrosion of steel $10\left(k_{0}=59-230 \mathrm{~g} /\left(\mathrm{m}^{2} \cdot \mathrm{h}\right)\right)$ in $5-25 \% \mathrm{H}_{2} \mathrm{SO}_{4}\left(80^{\circ} \mathrm{C}\right)$ to give $k \leq 3.0 \mathrm{~g} /\left(\mathrm{m}^{2} \cdot \mathrm{h}\right)$. In contrast, I-1-A weakly inhibits corrosion in this environment. In $5 \% \mathrm{HCl}$ $\left(100^{\circ} \mathrm{C}\right)$, addition of $0.5 \%$ catapin $\mathrm{K}$ slows down the corrosion of chromium-nickel steels $\operatorname{Kh} 17 N 13 \mathrm{M} 3 \mathrm{~T}\left(k_{0}=100 \mathrm{~g} /\left(\mathrm{m}^{2} \cdot \mathrm{h}\right)\right)$ and $\mathrm{Kh} 17 \mathrm{~N} 13 \mathrm{M} 2 \mathrm{~T}\left(k_{0}=114 \mathrm{~g} /\left(\mathrm{m}^{2} \cdot \mathrm{h}\right)\right)$ to $k=12$ and $3.0 \mathrm{~g} /\left(\mathrm{m}^{2} \cdot \mathrm{h}\right)$, respectively [10]. The corrosion of chromium-nickel steels is poorly inhibited by combinations of catapin $\mathrm{K}$ with urotropine. For example, for steel Kh17N13M2T in the presence of a formulation of $0.5 \%$ catapin $\mathrm{K}+0.5 \%$ urotropine, $k=4.8 \mathrm{~g} /\left(\mathrm{m}^{2} \cdot \mathrm{h}\right)$. Works $[9,10]$ do not report data on the protection of steels at $t>100^{\circ} \mathrm{C}$, but catapin $\mathrm{K}$ and I-1-A decompose in acid solution in 5 days [9]. In hot acid solutions, these CIs will be less stable, so they cannot be efficiently used in high-temperature media. Other things being equal, pyridine derivatives inhibit corrosion more weakly than UCs with similar structures. In fact, in the case of steel 45 corrosion in $14 \% \mathrm{HCl}$ at $100^{\circ} \mathrm{C}\left(k_{0}=2020 \mathrm{~g} /\left(\mathrm{m}^{2} \cdot \mathrm{h}\right)\right)$, the following compound $(1 \%)$

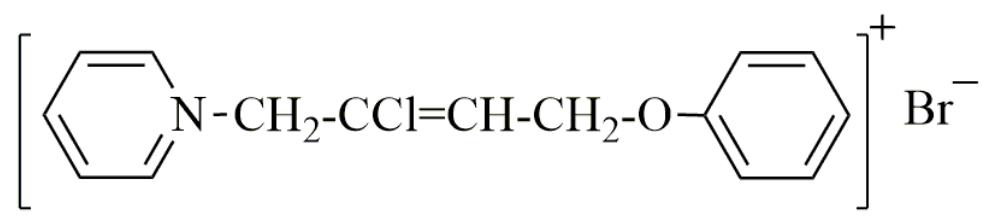

provides an inhibition coefficient of $\gamma=77$, whereas an equal amount of

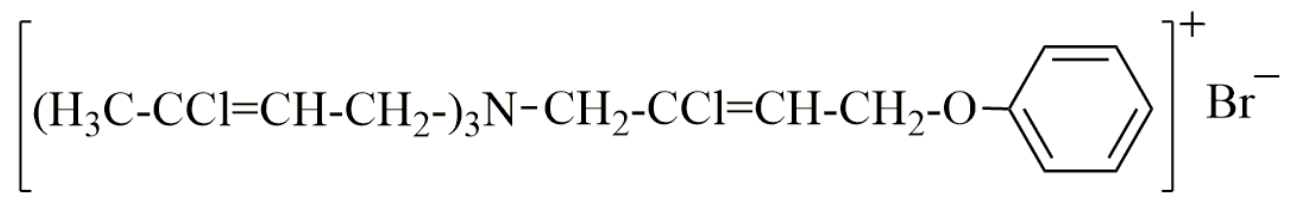

gives $\gamma=326[11]$.

Along with pyridine derivatives, quinoline derivatives with bulky unsaturated substituents can be used to slow down the corrosion of low carbon steels in hot $\mathrm{HCl}$ [1214]. For example, in the case of steel 3 corrosion in $14 \% \mathrm{HCl}$ at $95^{\circ} \mathrm{C}\left(k_{0}=2240 \mathrm{~g} /\left(\mathrm{m}^{2} \cdot \mathrm{h}\right)\right)$, the most efficient protection provided by

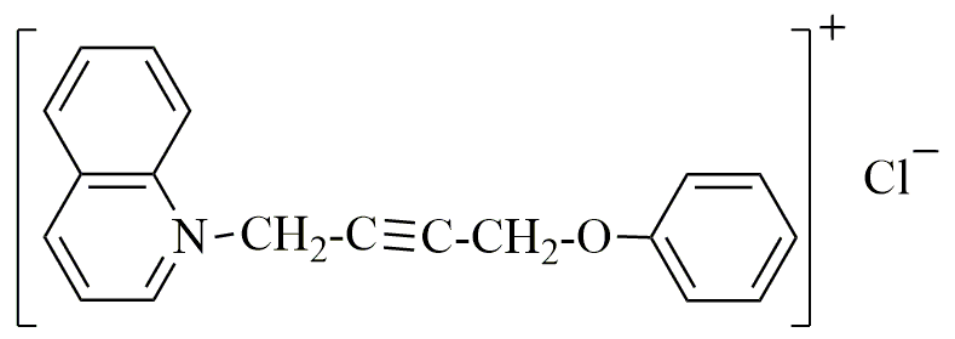

in the presence of which $(1 \%) k=2.5 \mathrm{~g} /\left(\mathrm{m}^{2} \cdot \mathrm{h}\right)$.

The patent [15] provides data on the protection of steel $\mathrm{P} 110$ in $15 \% \mathrm{HCl}\left(107^{\circ} \mathrm{C}\right)$ by formulations based on the berberine alkaloid: 


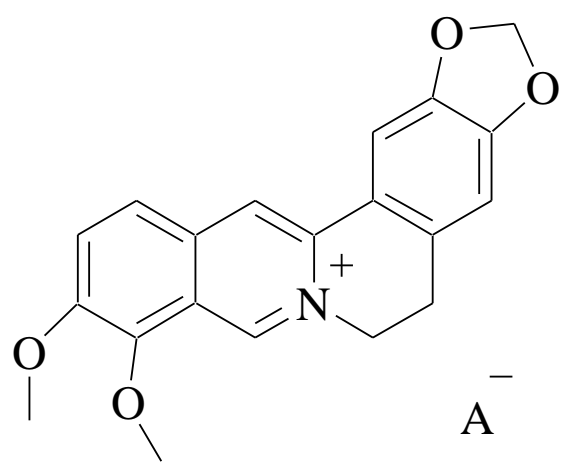

In fact, in the presence of a formulation of $0.7 \%$ crude berberine extract, $0.5 \%$ urotropine, and $0.36 \% \mathrm{H} 1 \mathrm{I}-1$ 24B $\mathrm{B}^{\mathrm{TM}} \mathrm{CI}$ enhancer (manufactured by Halliburton Energy Services, Inc., Houston, Texas), the $k$ value is $37 \mathrm{~g} /\left(\mathrm{m}^{2} \cdot \mathrm{h}\right)$, whereas in the presence of $0.5 \%$ urotropine and $0.36 \%$ of the CI enhancer, $k=187 \mathrm{~g} /\left(\mathrm{m}^{2} \cdot \mathrm{h}\right)$.

NHC derivatives containing quaternized nitrogen are mainly used to protect steels in acids. Quaternary ammonium salts (QAS) are close to this group of compounds. However, their use in high-temperature environments, even in inhibitor formulations, does not give good results. In fact, in the presence of 3\% HOSP-10 (an industrial CI), which is a mixture of QAS, a foaming agent and a synergist, steel D in $12 \% \mathrm{HCl}(30 \mathrm{~atm})$ at $t=100,140$, and $160^{\circ} \mathrm{C}$ gives $k=128,705$ and $1190 \mathrm{~g} /\left(\mathrm{m}^{2} \cdot \mathrm{h}\right)$, which corresponds to the degree of protection $Z=95.4,81.4$ and $74.8 \%$, respectively [16]. Thus, the presence of an NHC fragment in the structure of the organic cation should make it possible to protect steels by such a cation under high-temperature corrosion conditions.

More detailed information on the use of six-membered NHCs for the protection of steels in high-temperature acids in individual form or in formulations based on them is not reported. This indirectly indicates that they are not promising as HCIs, though pyridine and quinoline derivatives are often added to HCI formulations based on UCs, as we discussed earlier [1]. Moreover, pyridine and quinoline derivatives are toxic, which strongly restricts their practical application.

Five-membered NHCs can serve as an alternative to six-membered NHCs for the protection of steels in hot acid solutions. In the earliest study, benzimidazole derivatives were studied as HCIs [17]. In $14 \% \mathrm{HCl}\left(100^{\circ} \mathrm{C}\right)$ for steel $3\left(k_{0}=2080 \mathrm{~g} /\left(\mathrm{m}^{2} \cdot \mathrm{h}\right)\right)$ in the presence of the most efficient derivative (1\%),

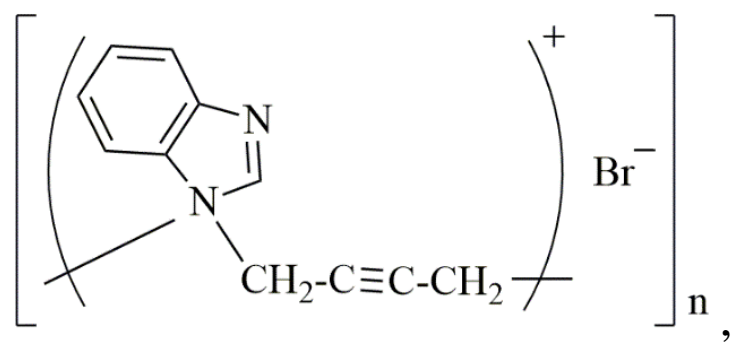

$k=11 \mathrm{~g} /\left(\mathrm{m}^{2} \cdot \mathrm{h}\right)$. Later, M.A. Quraishi studied derivatives of 1,2,4-triazole [18, 19], 1-oxa3,4-diazole [20], and thiazole [21] as CIs in hot $\mathrm{HCl}$ solutions. 
In $15 \% \mathrm{HCl}\left(105^{\circ} \mathrm{C}\right)$ for mild steel $\left(k_{0}=11150 \mathrm{~g} /\left(\mathrm{m}^{2} \cdot \mathrm{h}\right)\right.$ in the presence of $5000 \mathrm{ppm}$ $\mathrm{N}$-cinnamylidene-3-propyl-5-mercapto-1,2,4-triazole-4-amine

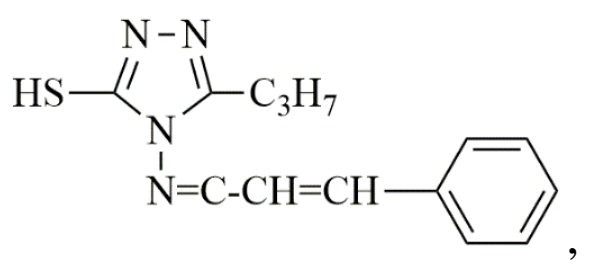

$k=49 \mathrm{~g} /\left(\mathrm{m}^{2} \cdot \mathrm{h}\right)$, which is higher than with an equivalent (by weight) addition of the wellknown acetylenic HCI, viz., propargyl alcohol (PA) $\left(k=33 \mathrm{~g} /\left(\mathrm{m}^{2} \cdot \mathrm{h}\right)\right)$ [18]. The following compound provides poorer steel protection:<smiles>C=CCc1nnc(S)n1-c1ccccc1</smiles>

In boiling $15 \% \mathrm{HCl}\left(105^{\circ} \mathrm{C}\right)$, addition of $5000 \mathrm{ppm}$ of this compound decreases the $k$ of mild steel $\left(k_{0}=12800 \mathrm{~g} /\left(\mathrm{m}^{2} \cdot \mathrm{h}\right)\right)$ to $488 \mathrm{~g} /\left(\mathrm{m}^{2} \cdot \mathrm{h}\right)$ [19].

The most efficient 1-oxa-3,4-diazole derivative, namely, 2-undecyl-5-mercapto-1-oxa3,4-diazole (5000 $\mathrm{ppm}$ ), in $15 \% \mathrm{HCl}$ provides $Z=72 \%$ for cold rolled mild steel and $Z=92.6-94.5 \%$ for steel $\mathrm{N} 80$, depending on the duration of corrosion tests [20].<smiles>CCCc1nnc(S)o1</smiles>

Structurally similar compounds, 2-heptadecenyl-5-mercapto-1-oxa-3,4-diazole and 2decenyl-5-mercapto-1-oxa-3,4-diazole containing unsaturated hydrocarbon radicals, are inferior to it in the protective action. Substituted thiazole (2000 ppm)

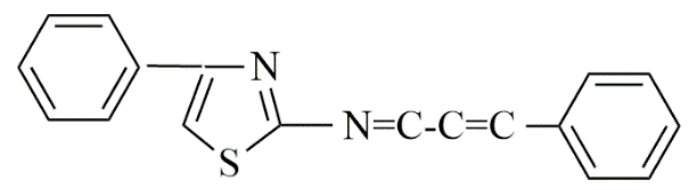

in $15 \% \mathrm{HCl}\left(105^{\circ} \mathrm{C}\right)$ on mild steel $\left(k_{0}=11150 \mathrm{~g} /\left(\mathrm{m}^{2} \cdot \mathrm{h}\right)\right)$ reduces $k$ to $202 \mathrm{~g} /\left(\mathrm{m}^{2} \cdot \mathrm{h}\right)$, which is significantly lower than that provided by $2000 \mathrm{ppm}$ PA $\left(k=8490 \mathrm{~g} /\left(\mathrm{m}^{2} \cdot \mathrm{h}\right)\right)$ [21]. The CAHMT inhibitor (the composition is not disclosed) [22] also deserves attention. It contains an azomethine bond conjugated with a $\mathrm{C}=\mathrm{C}$ group, a heterocycle containing three nitrogen atoms, and a sulfide group. The CI developers position it as "environmentally friendly". At $C_{\text {in }}$ up to $5000 \mathrm{ppm}$, it reduces the $k$ of $\mathrm{N} 80$ steel in $15 \% \mathrm{HCl}\left(105^{\circ} \mathrm{C}\right)$ to $102 \mathrm{~g} /\left(\mathrm{m}^{2} \cdot \mathrm{h}\right)$ 
$(Z=98.4-99.2 \%)$, but parallel studies show that the same amount of PA slows down the corrosion better and allows one to reach a minimum rate of about $40 \mathrm{~g} /\left(\mathrm{m}^{2} \cdot \mathrm{h}\right)$.

Information on the protection of steels by derivatives of five-membered NHCs considered above is limited to $t=105^{\circ} \mathrm{C}$, which does not allow us to fully understand the feasibility of their application at higher temperatures. All of these compounds, except for 2undecyl-5-mercapto-1-oxa-3,4-diazole, are modified by substituents comprising unsaturated carbon-carbon bonds. This feature of their structure indicates that the high efficiency of CIs in inhibiting the corrosion of steels in hot $\mathrm{HCl}$ solutions will be largely due to the formation of a polymer film on the steel surface upon deep chemical conversion of these compounds on the steel surface $[23,24]$. It should be understood that the presence of unsaturated bonds in their structure will give them the main disadvantage inherent in UCs, i.e., low stability in hot acid solutions that eliminates the $\mathrm{CI}$ from the corrosive environment. Moreover, it is known that $\mathrm{UCs}$ are efficient only in $\mathrm{HCl}$ solutions but not in other mineral acids $\left(\mathrm{H}_{2} \mathrm{SO}_{4}\right.$, $\mathrm{H}_{3} \mathrm{PO}_{4}$, and $\mathrm{HClO}_{4}$ ). All these factors can significantly limit the practical application of these compounds as HCIs.

From our point of view, NHC derivatives containing substituents without unsaturated carbon-carbon bonds, which should increase their chemical and thermal stability, are more promising as HCIs. Triazoles should be used as a basis for creating such HCIs. It is well known [25] that triazole rings can be chemically and thermally stable. An important property of triazoles is their ability to form strong complex compounds with metal cations, including iron [26-31]. This property indirectly indicates the ability of compounds containing a triazole moiety to chemically bind to steel surface through it, which should favor the most durable retention of such a CI on the metal. It is interesting that interaction of substituted triazoles with metal cations often results in polynuclear polymeric complex compounds with various structures in which they act as bidentate bridging ligands that bind metal cations, including $\mathrm{Fe}$ (II) [26-28]. If such structures are formed from triazole and $\mathrm{Fe}$ (II) cations on steel and they are strongly bound to its surface, efficient protection of the metal in corrosive media can be anticipated.

Indeed, 1,2,4-triazole derivatives efficiently protect steel in hot acid solutions. For example, $5 \mathrm{mM}$ of 4-substituted 1,2,4-triazole (IFKhAN-96) in $2 \mathrm{M} \mathrm{HCl}\left(95^{\circ} \mathrm{C}\right)$ slows down the corrosion of steel $3\left(k_{0}=1031 \mathrm{~g} /\left(\mathrm{m}^{2} \cdot \mathrm{h}\right)\right.$ by a factor of 69 [32]. Under the same conditions, an industrially produced $\mathrm{QAC}$, catamine $\mathrm{AB}$ (alkylbenzyldimethylammonium chloride $\left[\mathrm{C}_{\mathrm{n}} \mathrm{H}_{2 n+1} \mathrm{~N}^{+}\left(\mathrm{CH}_{3}\right)_{2} \mathrm{CH}_{2} \mathrm{C}_{6} \mathrm{H}_{5}\right] \mathrm{Cl}^{-}$, where $\left.n=10-18\right)$, slows down the corrosion only 24-fold. The temperature maximum of IFKhAN-96 efficiency is about $80^{\circ} \mathrm{C}$, which formally allows us to consider it as an HCI. As a disadvantage of this CI, it may be noted that it strongly accelerates steel corrosion at $t>80^{\circ} \mathrm{C}$ compared to lower temperatures. The corrosion of steel 3 is significantly hindered by IFKhAN-94, which is a 3-substituted 1,2,4-triazole [33]. At its $C=5 \mathrm{mM}$ in $2 \mathrm{M} \mathrm{HCl}\left(95^{\circ} \mathrm{C}\right), k$ decreases 93 -fold, but the temperature maximum of its efficiency also lies at temperatures close to $80^{\circ} \mathrm{C}$. Along with the corrosion inhibition in $\mathrm{HCl}$ solutions, IFKhAN-94 efficiently inhibits the corrosion of steel $3\left(k_{0}=1033 \mathrm{~g} /\left(\mathrm{m}^{2} \cdot \mathrm{h}\right)\right)$ in $2 \mathrm{M} \mathrm{H}_{2} \mathrm{SO}_{4}\left(95^{\circ} \mathrm{C}\right)$, providing an inhibition coefficient of $\gamma=610$. In the same 
environment, $5 \mathrm{mM}$ catamine AB protects steel 3 much worse $(\gamma=63)$. Unfortunately, these CIs do not offer equally high protective effects in $\mathrm{H}_{3} \mathrm{PO}_{4}$. In $2 \mathrm{M} \mathrm{H}_{3} \mathrm{PO}_{4}\left(95^{\circ} \mathrm{C}\right)$ for steel 3 $\left(k_{0}=519 \mathrm{~g} /\left(\mathrm{m}^{2} \cdot \mathrm{h}\right)\right)$ in the presence of these CIs, $\gamma=2.6$ and 3.1, respectively. IFKhAN-93, a 3 -substituted 1,2,4-triazole, is efficient in the protection of steel 3 in hot solutions of $\mathrm{HCl}$ and $\mathrm{H}_{2} \mathrm{SO}_{4}$, but it was studied only up to $t=80^{\circ} \mathrm{C}$ [34].

Along with 1,2,4-triazole derivatives, the protection of steels in hot acid solutions is provided by some tetrazole derivatives [35]. For example, IFKhAN-95, a 5-substituted tetrazole, inhibits the corrosion of steel 3111 - and 103 -fold in $2 \mathrm{M} \mathrm{HCl}$ and $\mathrm{H}_{2} \mathrm{SO}_{4}\left(95^{\circ} \mathrm{C}\right)$, respectively. It is interesting that lower molecular weight tetrazoles such as 5phenyltetrazole and 5-(2-dimethylaminoethyl)tetrazole provide $\gamma \leq 4.6$ even at $t \leq 80^{\circ} \mathrm{C}$. In both acids in the selected $t$ range of $25-95^{\circ} \mathrm{C}$, the maximum of $\mathrm{CI}$ efficiency was not reached, indicating that it lies no lower than at $95^{\circ} \mathrm{C}$. This is typical of HCIs.

Table 2. Corrosion rates $\left(k, \mathrm{~g} /\left(\mathrm{m}^{2} \cdot \mathrm{h}\right)\right)$ and corrosion inhibition coefficients $(\gamma)$ of steel 20 in $2 \mathrm{M} \mathrm{HCl}$ with addition of an IFKhAN-92 + urotropine mixture at various temperatures.

\begin{tabular}{|c|c|c|c|c|c|c|}
\hline \multirow{3}{*}{ Inhibitor } & \multicolumn{6}{|c|}{ Test duration } \\
\hline & \multicolumn{2}{|l|}{$0.5 \mathrm{~h}$} & \multicolumn{2}{|l|}{$1.0 \mathrm{~h}$} & \multicolumn{2}{|l|}{$2.0 \mathrm{~h}$} \\
\hline & $k, \mathbf{g} /\left(\mathbf{m}^{2} \cdot \mathbf{h}\right)$ & $\gamma$ & $k, g /\left(\mathbf{m}^{2} \cdot \mathbf{h}\right)$ & $\gamma$ & $k, \mathbf{g} /\left(\mathbf{m}^{2} \cdot \mathbf{h}\right)$ & $\gamma$ \\
\hline \multicolumn{7}{|c|}{$\mathbf{0}^{\circ} \mathrm{C}$} \\
\hline $10 \mathrm{mM}$ IFKhAN-92 + $10 \mathrm{mM}$ urotropine & 0.14 & 28.6 & 0.11 & 22.7 & 0.08 & 23.8 \\
\hline \multicolumn{7}{|c|}{$20^{\circ} \mathrm{C}$} \\
\hline $10 \mathrm{mM}$ IFKhAN-92 + $10 \mathrm{mM}$ urotropine & 0.24 & 40.8 & 0.14 & 63.6 & 0.10 & 56.0 \\
\hline \multicolumn{7}{|c|}{$40^{\circ} \mathrm{C}$} \\
\hline $10 \mathrm{mM}$ IFKhAN-92 + $10 \mathrm{mM}$ urotropine & 0.34 & 110 & 0.27 & 119 & 0.25 & 113 \\
\hline \multicolumn{7}{|c|}{$60^{\circ} \mathrm{C}$} \\
\hline $10 \mathrm{mM}$ IFKhAN-92 + $10 \mathrm{mM}$ urotropine & 0.98 & 93.1 & 0.91 & 92.9 & 0.86 & 96.5 \\
\hline \multicolumn{7}{|c|}{$80^{\circ} \mathrm{C}$} \\
\hline $10 \mathrm{mM}$ IFKhAN-92 + $10 \mathrm{mM}$ urotropine & 2.86 & 140 & 2.40 & 165 & 1.66 & 224 \\
\hline \multicolumn{7}{|c|}{$100^{\circ} \mathrm{C}$} \\
\hline $10 \mathrm{mM}$ IFKhAN-92 + $10 \mathrm{mM}$ urotropine & 10.5 & 148 & 8.1 & 188 & 7.1 & 197 \\
\hline $10 \mathrm{mM}$ IFKhAN-92 + $20 \mathrm{mM}$ urotropine & 10.3 & 150 & 8.2 & 185 & 8.0 & 175 \\
\hline \multicolumn{7}{|c|}{$120^{\circ} \mathrm{C}$} \\
\hline $5 \mathrm{mM}$ IFKhAN-92 + $10 \mathrm{mM}$ urotropine & 19.5 & 255 & 16.0 & 259 & 17.8 & - \\
\hline $10 \mathrm{mM}$ IFKhAN-92 + $10 \mathrm{mM}$ urotropine & 19.5 & 255 & 15.9 & 261 & 17.1 & - \\
\hline $20 \mathrm{mM}$ IFKhAN-92 + $20 \mathrm{mM}$ urotropine & 16.0 & 312 & 12.6 & 329 & 17.0 & - \\
\hline
\end{tabular}


Test duration

\begin{tabular}{|c|c|c|c|c|c|c|}
\hline \multirow{3}{*}{ Inhibitor } & \multirow{2}{*}{\multicolumn{2}{|c|}{$0.5 \mathrm{~h}$}} & \multirow{2}{*}{\multicolumn{2}{|c|}{$1.0 \mathrm{~h}$}} & \multirow{2}{*}{\multicolumn{2}{|c|}{$2.0 \mathrm{~h}$}} \\
\hline & & & & & & \\
\hline & $k, \mathbf{g} /\left(\mathbf{m}^{2} \cdot \mathbf{h}\right)$ & $\gamma$ & $k, \mathbf{g} /\left(\mathbf{m}^{2} \cdot \mathbf{h}\right)$ & $\gamma$ & $k, \mathbf{g} /\left(\mathbf{m}^{2} \cdot \mathbf{h}\right)$ & $\gamma$ \\
\hline \multicolumn{7}{|c|}{$140^{\circ} \mathrm{C}$} \\
\hline $10 \mathrm{mM}$ IFKhAN-92 + $10 \mathrm{mM}$ urotropine & 298 & 27.0 & 211 & - & 144 & - \\
\hline $20 \mathrm{mM}$ IFKhAN-92 + $20 \mathrm{mM}$ urotropine & 130 & 62.0 & 101 & - & 109 & - \\
\hline $20 \mathrm{mM}$ IFKhAN-92 + $100 \mathrm{mM}$ urotropine & 49.6 & 163 & 65.0 & - & 68.9 & - \\
\hline \multicolumn{7}{|c|}{$160^{\circ} \mathrm{C}$} \\
\hline $20 \mathrm{mM}$ IFKhAN-92 + $100 \mathrm{mM}$ urotropine & 248 & 50 & 284 & - & 393 & - \\
\hline
\end{tabular}

The most promising results in the protection of steels in hot acid solutions are shown by IFKhAN-92, a 3-substituted 1,2,4-triazole. IFKhAN-92 itself efficiently inhibits the corrosion of steel 20 in $2 \mathrm{M} \mathrm{HCl}$ at $t \leq 100^{\circ} \mathrm{C}$ (Figure 2), thus significantly surpassing catamine $\mathrm{AB}$ [36]. From a practical point of view, formulations of IFKHAN-92 with urotropine that slow down the corrosion of steel at $t \leq 160^{\circ} \mathrm{C}$ (Table 2) are important. Formulations of IFKhAN-92 with urotropine inhibit the corrosion of steel 20 in $\mathrm{HCl}$ solutions in a wide range of $\mathrm{HCl}$ concentrations, $C_{\mathrm{HCl}}=2-6 \mathrm{M}$ (Table 3). At the same time, urotropine itself has little effect on the corrosion in hot $\mathrm{HCl}$ solutions. In the absence of a $\mathrm{CI}$, the corrosion rate of the samples decreases with exposure due to consumption of the acid in the reaction with iron. In contrast, it often increases in inhibited solutions. However, even at $160^{\circ} \mathrm{C}$ the $k$ values obtained in 0.5 - and 2-hour tests differ only 1.6-fold.

Table 3. Corrosion rates $\left(k, \mathrm{~g} /\left(\mathrm{m}^{2} \cdot \mathrm{h}\right)\right)$ and corrosion inhibition coefficients $(\gamma)$ of steel 20 in 4 and $6 \mathrm{M} \mathrm{HCl}$ with addition of an IFKhAN-92 + urotropine mixture at various temperatures.

\section{Test duration}

\begin{tabular}{|c|c|c|c|c|c|c|c|}
\hline \multirow[t]{2}{*}{ Inhibitor } & \multirow[t]{2}{*}{ Acid } & \multicolumn{2}{|c|}{$0.5 \mathrm{~h}$} & \multicolumn{2}{|c|}{$1.0 \mathrm{~h}$} & \multicolumn{2}{|c|}{$2.0 \mathrm{~h}$} \\
\hline & & $k, \mathbf{g} /\left(\mathbf{m}^{2} \cdot \mathbf{h}\right)$ & $\gamma$ & $k, \mathbf{g} /\left(\mathbf{m}^{2} \cdot \mathbf{h}\right)$ & $\gamma$ & $k, \mathbf{g} /\left(\mathbf{m}^{2} \cdot \mathbf{h}\right)$ & $\gamma$ \\
\hline \multicolumn{8}{|c|}{$100^{\circ} \mathrm{C}$} \\
\hline \multirow{2}{*}{-} & $4 \mathrm{M}$ & 3380 & - & 3100 & - & 2720 & - \\
\hline & $6 \mathrm{M}$ & 4970 & - & 4610 & - & 4020 & - \\
\hline \multirow{2}{*}{$\begin{array}{l}10 \mathrm{mM} \text { IFKhAN-92 + } \\
10 \mathrm{mM} \text { urotropine }\end{array}$} & $4 \mathrm{M}$ & 12.1 & 279 & 8.7 & 356 & 17.0 & 160 \\
\hline & $6 \mathrm{M}$ & 21.3 & 233 & 20.0 & 231 & 30.1 & 134 \\
\hline \multirow{2}{*}{$\begin{array}{l}20 \text { mM IFKhAN-92 + } \\
20 \mathrm{mM} \text { urotropine }\end{array}$} & $4 \mathrm{M}$ & - & - & - & - & 16.8 & 162 \\
\hline & $6 \mathrm{M}$ & - & - & - & - & 30.0 & 134 \\
\hline
\end{tabular}




\section{Test duration}

\begin{tabular}{|c|c|c|c|c|c|c|c|}
\hline \multirow[t]{2}{*}{ Inhibitor } & \multirow[t]{2}{*}{ Acid } & \multicolumn{2}{|c|}{$0.5 \mathrm{~h}$} & \multicolumn{2}{|c|}{$1.0 \mathrm{~h}$} & \multicolumn{2}{|c|}{$2.0 \mathrm{~h}$} \\
\hline & & $k, \mathbf{g} /\left(\mathbf{m}^{2} \cdot \mathbf{h}\right)$ & $\gamma$ & $k, \mathbf{g} /\left(\mathbf{m}^{2} \cdot \mathbf{h}\right)$ & $\gamma$ & $k, \mathrm{~g} /\left(\mathbf{m}^{2} \cdot \mathbf{h}\right)$ & $\gamma$ \\
\hline \multirow{2}{*}{$\begin{array}{c}10 \mathrm{mM} \text { IFKhAN-92 + } \\
100 \mathrm{mM} \text { urotropine }\end{array}$} & $4 \mathrm{M}$ & 12.7 & 266 & 8.3 & 373 & 13.3 & 205 \\
\hline & $6 \mathrm{M}$ & 20.6 & 241 & 14.0 & 329 & 14.5 & 277 \\
\hline \multicolumn{8}{|c|}{$120^{\circ} \mathrm{C}$} \\
\hline \multirow{2}{*}{-} & $4 \mathrm{M}$ & 6630 & - & - & - & - & - \\
\hline & $6 \mathrm{M}$ & 9340 & - & - & - & - & - \\
\hline \multirow{2}{*}{$\begin{array}{l}10 \mathrm{mM} \text { IFKhAN-92 + } \\
100 \mathrm{mM} \text { urotropine }\end{array}$} & $4 \mathrm{M}$ & 22.9 & 290 & 25.6 & - & 29.9 & - \\
\hline & $6 \mathrm{M}$ & 43.7 & 214 & 51.5 & - & 60.4 & - \\
\hline \multicolumn{8}{|c|}{$140^{\circ} \mathrm{C}$} \\
\hline- & $4 \mathrm{M}$ & 12000 & - & - & - & - & - \\
\hline $\begin{array}{l}20 \text { mM IFKhAN-92 + } \\
100 \text { mM urotropine }\end{array}$ & $4 \mathrm{M}$ & 129 & 93.0 & 146 & - & 166 & - \\
\hline
\end{tabular}

A unique feature of formulations based on IFKhAN-92 is the ability to slow down the corrosion of steel in $\mathrm{H}_{2} \mathrm{SO}_{4}$ solutions at $t \leq 200^{\circ} \mathrm{C}$ [37]. IFKhAN-92 at $C=20 \mathrm{mM}$ significantly inhibits the corrosion of steel 20 up to $t=140^{\circ} \mathrm{C}$, whereas catamine AB does so only up to $100^{\circ} \mathrm{C}$. Binary formulations of IFKhAN-92 with $\mathrm{KI}$ or $\mathrm{KBr}$ protect steel up to $t \leq 200^{\circ} \mathrm{C}$ (Table 4). An increase in the duration of corrosion tests does not lead to a significant acceleration of steel 20 corrosion, both in the presence of IFKhAN-92 itself and with binary mixtures. Though the protective effects of the IFKhAN-92 mixture with $\mathrm{KBr}$ are lower than with KI, this mixture is more promising for practice since it does not contain expensive KI. The high efficiency of the mixture of IFKhAN-92 with KI in the protection of steel 3 in $2 \mathrm{M} \mathrm{H}_{2} \mathrm{SO}_{4}\left(t \leq 140^{\circ} \mathrm{C}\right)$ was shown in [38].

It is important that no information on such efficient inhibitory protection of steels in high-temperature $\mathrm{H}_{2} \mathrm{SO}_{4}$ solutions is available in literature. In fact, according to M.A. Kuraishi [39], the macrocyclic compound 2,3,9,10-tetramethyl-6,13-dithia1,4,5,7,8,11,12,14-octaaza-cyclotetradeca-1,3,6,8,10,13-hexaene (MTAH) deserves attention for steel protection in hot $\mathrm{H}_{2} \mathrm{SO}_{4}$ solutions. This CI $(1000 \mathrm{ppm})$ provides $Z=88.9 \%$ in $20 \% \mathrm{H}_{2} \mathrm{SO}_{4}\left(95 \pm 2{ }^{\circ} \mathrm{C}\right)$ according to 10 min tests. $Z$ reaches $99.3 \%$ only for the formulation of $500 \mathrm{ppm}$ MTAH $+0.25 \% \mathrm{KI}$ [40]. However, it is not clear from the article how an increase in the exposure time will affect the protective effect of this CI, which is very important for its practical use. 

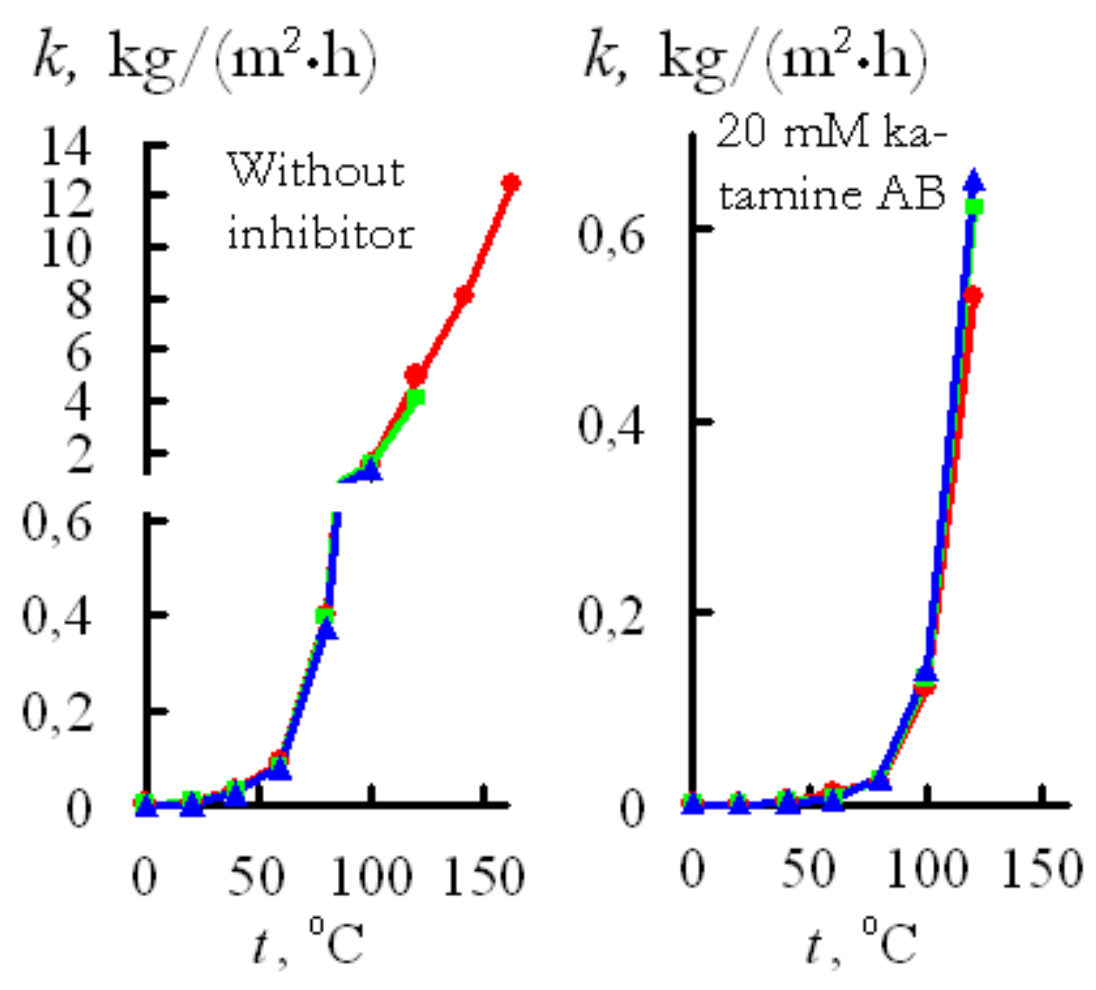

$k, \mathrm{~kg} /\left(\mathrm{m}^{2} \cdot \mathrm{h}\right)$

$k, \mathrm{~kg} /\left(\mathrm{m}^{2} \cdot \mathrm{h}\right)$

$k, \mathrm{~kg} /\left(\mathrm{m}^{2} \cdot \mathrm{h}\right)$
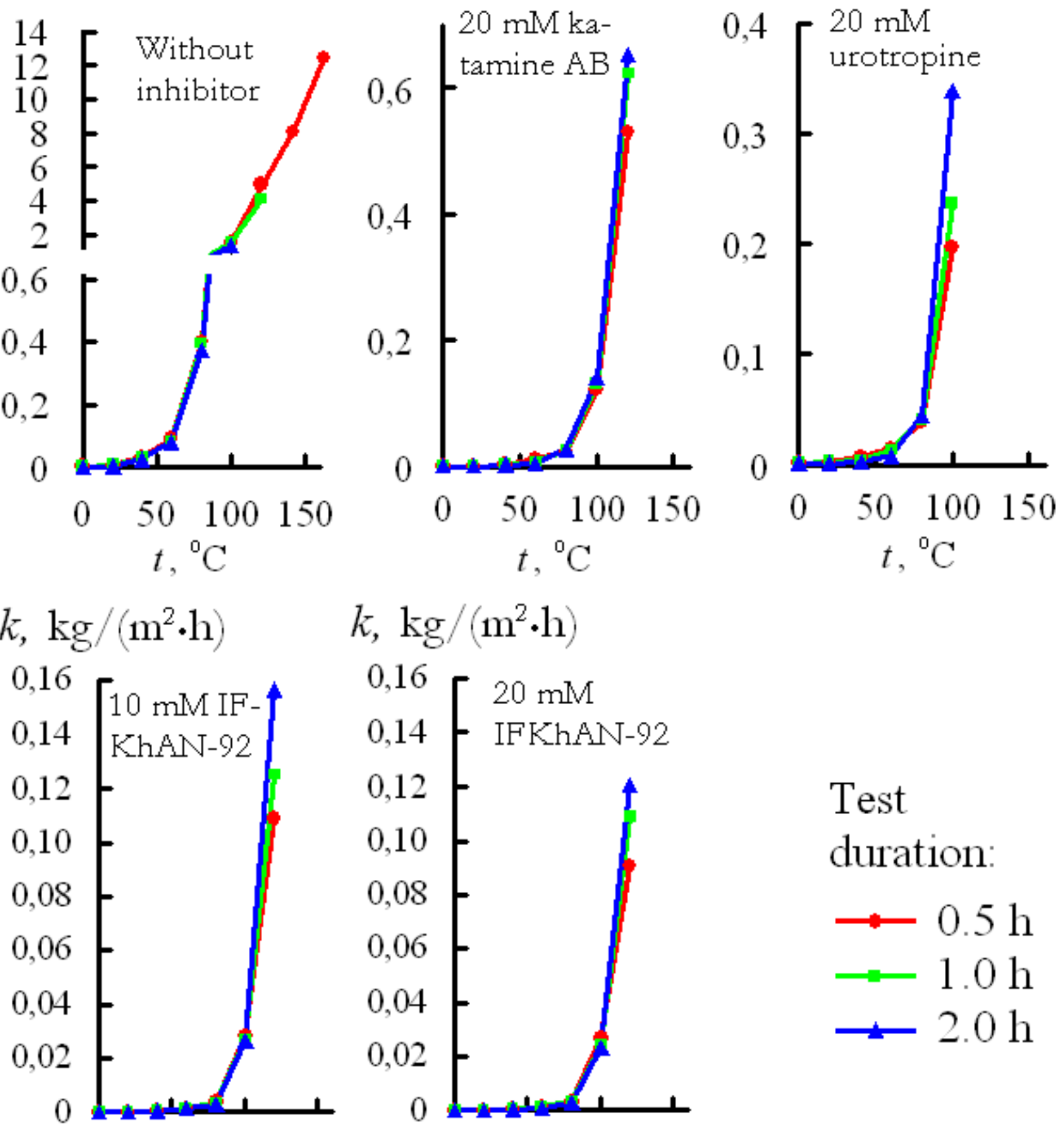
$\begin{array}{lllll}0 & 50 & 100 & 150\end{array}$
$t,{ }^{\circ} \mathrm{C}$

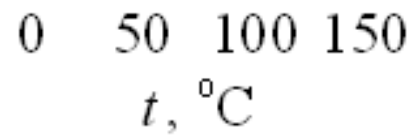

Test duration:
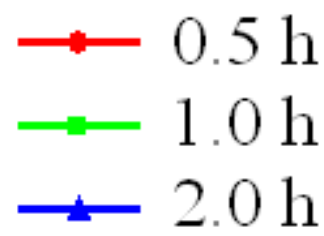

Figure 2. Corrosion rates of steel 20 in $2 \mathrm{M} \mathrm{HCl}$. 


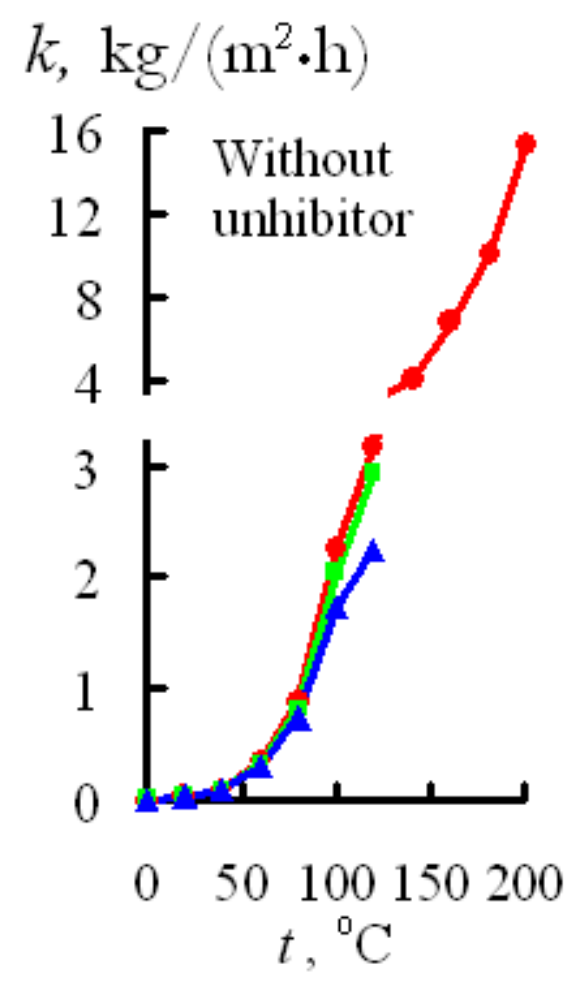

$k, \mathrm{~kg} /\left(\mathrm{m}^{2} \cdot \mathrm{h}\right)$

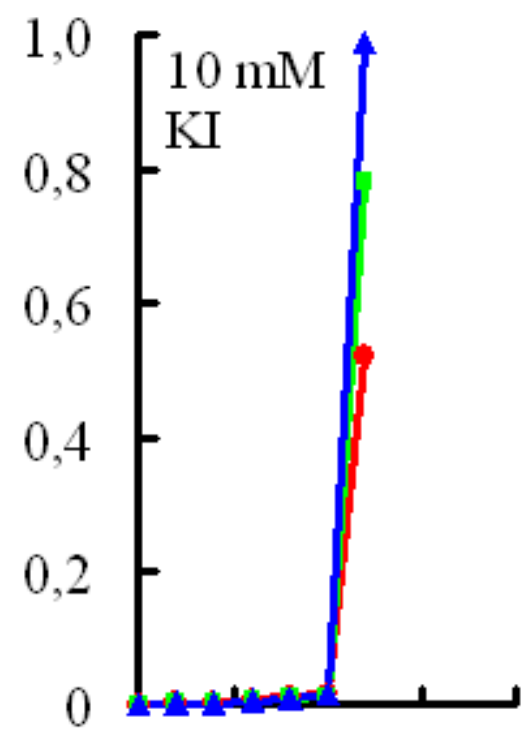

$0 \quad 50100150200$ $t,{ }^{\circ} \mathrm{C}$

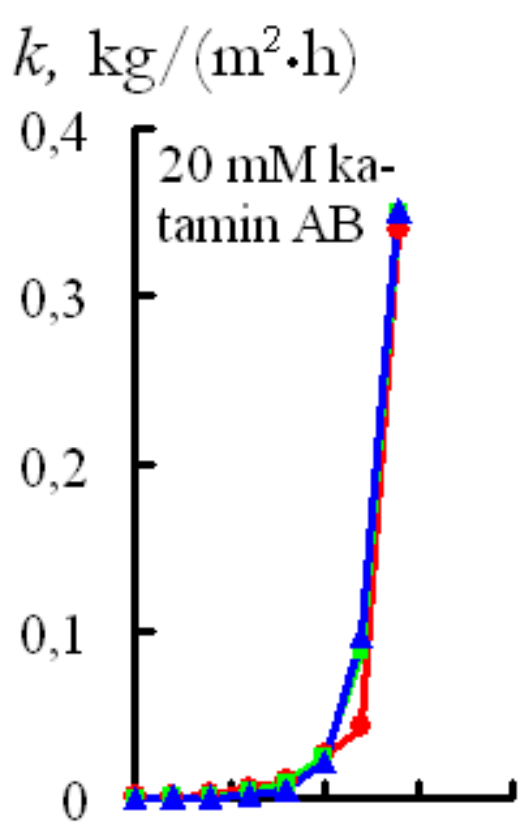

$0 \quad 50100150200$ $t,{ }^{\circ} \mathrm{C}$

$k, \mathrm{~kg} /\left(\mathrm{m}^{2} \cdot \mathrm{h}\right)$

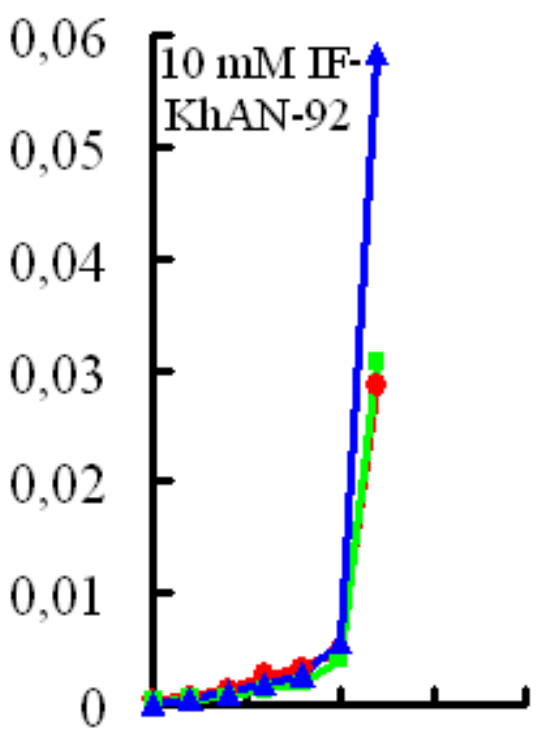

$k, \mathrm{~kg} /\left(\mathrm{m}^{2} \cdot \mathrm{h}\right)$

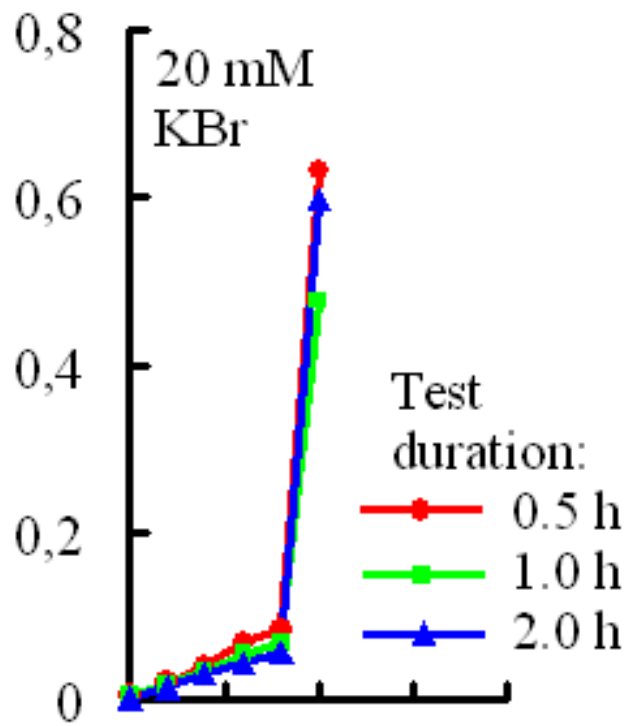

$k, \mathrm{~kg} /\left(\mathrm{m}^{2} \cdot \mathrm{h}\right)$

$0,4[20 \mathrm{mM}$ IFKhAN-92

0,

0,2

0,1

0

$0 \quad 50100150200$
$t,{ }^{\circ} \mathrm{C}$

Figure 3. Corrosion rates of steel 20 in $2 \mathrm{M} \mathrm{H}_{2} \mathrm{SO}_{4}$. 
Table 4. Corrosion rates $\left(k, \mathrm{~g} /\left(\mathrm{m}^{2} \cdot \mathrm{h}\right)\right)$ and corrosion inhibition coefficients $(\gamma)$ of steel 20 in $2 \mathrm{M} \mathrm{H}_{2} \mathrm{SO}_{4}$ with addition of IFKhAN-92 based mixtures at various temperatures.

\begin{tabular}{|c|c|c|c|c|c|c|}
\hline \multirow{3}{*}{ Inhibitor } & \multicolumn{6}{|c|}{ Test duration } \\
\hline & \multicolumn{2}{|c|}{$0.5 \mathrm{~h}$} & \multicolumn{2}{|l|}{$1.0 \mathrm{~h}$} & \multicolumn{2}{|c|}{$2.0 \mathrm{~h}$} \\
\hline & $k, \mathrm{~g} /\left(\mathbf{m}^{2} \cdot \mathbf{h}\right)$ & $\gamma$ & $k, \mathrm{~g} /\left(\mathbf{m}^{2} \cdot \mathbf{h}\right)$ & $\gamma$ & $k, g /\left(\mathbf{m}^{2} \cdot \mathbf{h}\right)$ & $\gamma$ \\
\hline \multicolumn{7}{|c|}{$0^{\circ} \mathrm{C}$} \\
\hline $5 \mathrm{mM}$ IFKhAN-92 + $5 \mathrm{mM} \mathrm{KI}$ & 0.21 & 45.2 & 0.12 & 95.8 & 0.09 & 95.5 \\
\hline $10 \mathrm{mM}$ IFKhAN $-92+10 \mathrm{mM} \mathrm{KBr}$ & 0.36 & 26.4 & 0.31 & 37.1 & 0.20 & 43.0 \\
\hline \multicolumn{7}{|c|}{$20^{\circ} \mathrm{C}$} \\
\hline 5 mM IFKhAN-92 + 5 mM KI & 0.31 & 145 & 0.17 & 211 & 0.16 & 207 \\
\hline 10 mM IFKhAN $-92+10 \mathrm{mM} \mathrm{KBr}$ & 0.52 & 86.5 & 0.41 & 87.8 & 0.31 & 107 \\
\hline \multicolumn{7}{|c|}{$40^{\circ} \mathrm{C}$} \\
\hline $5 \mathrm{mM}$ IFKhAN-92 + $5 \mathrm{mM} \mathrm{KI}$ & 0.49 & 214 & 0.20 & 475 & 0.19 & 487 \\
\hline 10 mM IFKhAN $-92+10$ mM KBr & 0.88 & 119 & 0.70 & 136 & 0.58 & 159 \\
\hline \multicolumn{7}{|c|}{$60^{\circ} \mathrm{C}$} \\
\hline $5 \mathrm{mM}$ IFKhAN-92 + $5 \mathrm{mM} \mathrm{KI}$ & 0.66 & 530 & 0.39 & 874 & 0.30 & 1050 \\
\hline $10 \mathrm{mM}$ IFKhAN $-92+10 \mathrm{mM} \mathrm{KBr}$ & 1.2 & 292 & 0.98 & 348 & 0.73 & 432 \\
\hline \multicolumn{7}{|c|}{$8^{\circ} \mathrm{C}$} \\
\hline $5 \mathrm{mM}$ IFKhAN-92 + $5 \mathrm{mM} \mathrm{KI}$ & 0.81 & 1090 & 0.58 & 1440 & 0.53 & 1400 \\
\hline $10 \mathrm{mM}$ IFKhAN $-92+10 \mathrm{mM} \mathrm{KBr}$ & 1.8 & 491 & 1.4 & 596 & 1.5 & 495 \\
\hline \multicolumn{7}{|c|}{$100^{\circ} \mathrm{C}$} \\
\hline $5 \mathrm{mM}$ IFKhAN-92 + $5 \mathrm{mM} \mathrm{KI}$ & 2.0 & 1130 & 1.4 & 1460 & 1.1 & 1580 \\
\hline $10 \mathrm{mM}$ IFKhAN $-92+10 \mathrm{mM} \mathrm{KBr}$ & 2.1 & 1080 & 1.7 & 1200 & 3.3 & 527 \\
\hline \multicolumn{7}{|c|}{$120^{\circ} \mathrm{C}$} \\
\hline $5 \mathrm{mM}$ IFKhAN-92 + $5 \mathrm{mM} \mathrm{KI}$ & 2.6 & 1220 & 2.4 & 1220 & 1.8 & 1240 \\
\hline 10 mM IFKhAN $-92+10 \mathrm{mM} \mathrm{KBr}$ & 3.7 & 854 & 2.1 & 1400 & 3.6 & 622 \\
\hline \multicolumn{7}{|c|}{$140^{\circ} \mathrm{C}$} \\
\hline 5 mM IFKhAN-92 + 5 mM KI & 4.5 & 898 & 3.2 & - & 2.7 & - \\
\hline 10 mM IFKhAN $-92+10 \mathrm{mM} \mathrm{KBr}$ & 18.9 & 214 & 11.2 & - & 18.0 & - \\
\hline
\end{tabular}


Test duration

\begin{tabular}{|c|c|c|c|c|c|c|}
\hline \multirow[t]{2}{*}{ Inhibitor } & \multicolumn{2}{|c|}{$0.5 \mathrm{~h}$} & \multicolumn{2}{|l|}{$1.0 \mathrm{~h}$} & \multicolumn{2}{|c|}{$2.0 \mathrm{~h}$} \\
\hline & $k, \mathrm{~g} /\left(\mathbf{m}^{2} \cdot \mathbf{h}\right)$ & $\gamma$ & $k, \mathrm{~g} /\left(\mathbf{m}^{2} \cdot \mathbf{h}\right)$ & $\gamma$ & $k, \mathrm{~g} /\left(\mathbf{m}^{2} \cdot \mathbf{h}\right)$ & $\gamma$ \\
\hline \multicolumn{7}{|c|}{$160^{\circ} \mathrm{C}$} \\
\hline $5 \mathrm{mM}$ IFKhAN-92 + $5 \mathrm{mM} \mathrm{KI}$ & 34.7 & 195 & 21.5 & - & 39.7 & - \\
\hline $10 \mathrm{mM}$ IFKhAN-92 + $5 \mathrm{mM} \mathrm{KI}$ & 19.2 & 353 & 20.0 & - & 37.8 & - \\
\hline $10 \mathrm{mM}$ IFKhAN $-92+10 \mathrm{mM} \mathrm{KBr}$ & 52.9 & 128 & 54.8 & - & 162 & - \\
\hline $20 \mathrm{mM}$ IFKhAN $-92+20 \mathrm{mM} \mathrm{KBr}$ & 50.1 & 135 & 49.1 & - & 71.0 & - \\
\hline \multicolumn{7}{|c|}{$180^{\circ} \mathrm{C}$} \\
\hline 10 mM IFKhAN-92 + 5 mM KI & 75.5 & 134 & 78.4 & - & 125 & - \\
\hline $20 \mathrm{mM}$ IFKhAN $-92+20 \mathrm{mM} \mathrm{KBr}$ & 100 & 101 & 133 & - & 164 & - \\
\hline \multicolumn{7}{|c|}{$200^{\circ} \mathrm{C}$} \\
\hline 10 mM IFKhAN-92 + 5 mM KI & 78.4 & 195 & 119 & - & 160 & - \\
\hline $20 \mathrm{mM}$ IFKhAN $-92+20 \mathrm{mM} \mathrm{KBr}$ & 237 & 64.6 & 217 & - & 198 & - \\
\hline
\end{tabular}

Stainless steels are most difficult to protect in acid solutions. The surfaces of these materials are heterogeneous in chemical composition, thus certain difficulties to the inhibition of the corrosion process are created. The corrosion of stainless steels in $\mathrm{HCl}$ solutions is hindered by IFKhAN-92 itself and the IFKhAN-92 + urotropine (molar ratio of components 1:1), IFKHAN-92+ KBr (1:9) and IFKHAN-92+KNCS (4:1) mixtures. These formulations inhibit the corrosion of $12 \mathrm{Kh} 18 \mathrm{~N} 10 \mathrm{~T}$ chromium-nickel steel in $2 \mathrm{M} \mathrm{HCl}$ and $2 \mathrm{M} \mathrm{H}_{2} \mathrm{SO}_{4}\left(t \leq 100^{\circ} \mathrm{C}\right)[41,42]$. In solutions of these acids $\left(t \leq 100^{\circ} \mathrm{C}\right)$ saturated with $\mathrm{H}_{2} \mathrm{~S}$, binary formulations of IFKhAN-92 significantly reduce corrosion and, especially important, hydrogenation of $1 \mathrm{Kh} 18 \mathrm{~N} 9 \mathrm{~T}$ chromium-nickel steel $[43,44]$.

The three-component formulation of IFKhAN-92 + KI + urotropine (1:1:4) [45-47] is most efficient in the protection of chromium-nickel steels. This mixture efficiently inhibits the corrosion of $08 \mathrm{Kh} 18 \mathrm{~N} 10 \mathrm{~T}$ chromium-nickel steel in $2 \mathrm{M} \mathrm{HCl}$ at $t$ up to $160^{\circ} \mathrm{C}$, as well as in $2 \mathrm{M} \mathrm{H}_{2} \mathrm{SO}_{4}$ at $t$ up to $180^{\circ} \mathrm{C}$ inclusive, and maintains the protective effect for at least 8 hours [45-47]. Along with chromium-nickel steels, the three-component HCI also protects low-carbon steels in the same $t$ ranges in $\mathrm{HCl}$ and $\mathrm{H}_{2} \mathrm{SO}_{4}$ solutions, which proves its versatility.

The protection of steels in $\mathrm{H}_{3} \mathrm{PO}_{4}$ solutions by inhibitors is a complex task [48]. The generalized information on the inhibitory protection of steels in this environment presented in the review [49] refers exclusively to $t \leq 75^{\circ} \mathrm{C}$. The CIs used for the protection of steels in this acid are usually studied at temperatures close to room temperature, while the rare reported data corresponding to higher temperatures indicate a significant decrease in their 
protective effect under these conditions [50-59]. In view of this, data on the protection of low-carbon steel in $\mathrm{H}_{3} \mathrm{PO}_{4}$ solutions by the IFKhAN-92 inhibitor are of interest. It was shown [60] that $5 \mathrm{mM}$ IFKhAN-92 weakly protects steel 3 in $2 \mathrm{M} \mathrm{H}_{3} \mathrm{PO}_{4}$ at $0-95^{\circ} \mathrm{C}\left(k_{0}=2.4-\right.$ $518 \mathrm{~g} /\left(\mathrm{m}^{2} \cdot \mathrm{h}\right)$ ), slowing down corrosion by a factor of $2.4-6.2$. Modifying this CI by adding $0.5 \mathrm{mM} \mathrm{KNCS}$ allows the maximum $k$ value in the range of $t=0-95^{\circ} \mathrm{C}$ to be reduced to $1.2 \mathrm{~g} /\left(\mathrm{m}^{2} \cdot \mathrm{h}\right)$, while addition of $0.5 \mathrm{mM}$ 2-mercaptobenzothiazole, to $1.1 \mathrm{~g} /\left(\mathrm{m}^{2} \cdot \mathrm{h}\right)$. By themselves, these additives fail to inhibit the corrosion of steel satisfactorily in this environment. The temperature maximum of efficiency was not achieved for either of the composite CIs, as it is characteristic of HCIs.

Organic acids are yet another important group of corrosive process fluids. A deception exists that they are not capable of exerting significant corrosive effects on steels with which they come into contact and that inhibitory protection of metals is not required in these environments. It was clearly shown in the first part of our review [7] that an increase in $t$ of these media significantly increases their corrosivity towards steels, making them unstable under these conditions. It should be noted that considerably fewer CIs are recommended for the protection of steels in organic acids than for mineral acid environments. There is but a narrow range of individual CIs that protect steels in hot organic acids. According to the data of 2 -hour testing in $20 \% \mathrm{HCOOH}\left(103 \pm 2^{\circ} \mathrm{C}\right)$, the following sulfur-containing compounds significantly inhibit the corrosion of mild steel $\left(k_{0}=405 \mathrm{~g} /\left(\mathrm{m}^{2} \cdot \mathrm{h}\right)\right)$ at $1000 \mathrm{ppm}$ concentration: ditolylthiourea $(Z=99.5 \%)$, 2-decenyl-5-mercapto-1-oxa-3,4-diazole $(Z=99.6 \%)$, 3-heptadecenyl-4-phenyl-5-mercapto-1,2,4-triazole $(Z=99.7 \%)$, 3-undecyl-4phenyl-5-mercapto-1,2,4-triazole $(Z=99.7 \%)$, and 3-decenyl-4-phenyl-5-mercapto-1,2,4triazole $(Z=99.8 \%)$ [39]. The range of CIs recommended for use in colder organic acids is mainly represented by NHCs. Literature sources report that mild steels can be protected in acetic acid solutions by aromatic nitrones [61], 3-alkyl-4-amino-5-mercapto-1,2,4-triazole (alkyl = methyl, ethyl, propyl and butyl) [62], 4-(N,N-dimethylamino)-benzylidineimino-3propyl-5-mercapto-1,2,4-triazole, 4-benzylidineimino-3-propyl-5-mercapto-1,2,4-triazole, 4-salicylideneimino-3-propyl-5-mercapto-1,2,4-triazole, 4-cinnamalideneimino-3-propyl5-mercapto-1,2,4-triazole [63], 3-heptadecenyl-4-phenyl-5-mercapto-1,2,4-triazole, 3undecyl-4-phenyl-5-mercapto-1,2,4-triazole, 3-decenyl-4-phenyl-5-mercapto-1,2,4-triazole [64], ditetrazole derivatives [65], tetrahydro-1,2,4,5-tetrazine-3-thione derivatives [66], 5alkyl-2-amino-1,3,4-thiadiazole (alkyl = methyl, ethyl and propyl) [67], and 1,2-alkane-bis(ethyl ammonium bromide) [68]. Some of them also exhibit a protective effect in formic acid solutions [62,63, 66, 67,69]. In formic acid, the corrosion of steel is inhibited by phenylthiourea, tolylthiourea, diphenylthiourea [70], 5-heptadec-8-enyl-4-phenyl-4H[1,2,4]triazole-3-thiol, 4-phenyl-5-undecyl-4H-[1,2,4]triazole-3-thiol, 5-dec-9-enyl-4phenyl-4H-[1,2,4]triazole-3-thiol [71], 2-heptadecenyl-5-mercapto-1-oxa-3,4-diazole, 2undecyl-5-mercapto-1-oxa-3,4-diazole, 2-decenyl-5-mercapto-1-oxa-3,4-diazole [72], alkanediyl- $\alpha, \omega$-bis(dimethylcetylammonium bromide) [73], undecenoic acid hydrazide, 1undecyl-4-phenylthiosemicarbazide, and 1-decenyl-4-phenylthiosemicarbazide [74]. Experimental data on the protection of steels by these compounds in organic acid solutions 
were mainly obtained in cold environments or in solutions with a maximum temperature of $60^{\circ} \mathrm{C}$, which does not allow one to judge on the prospects for the use of even the most efficient of them under high-temperature corrosion conditions. The industrial use of many of these CIs will be limited the instability of their protective effect over time and its loss with an increase in $t$. All this indicates that it is impossible to use these compounds in individual form for steel protection in $\mathrm{H}_{3} \mathrm{CCOOH}$ and $\mathrm{HCOOH}$ solutions under high-temperature corrosion conditions. It might be more promising to create mixed inhibitors based on some of these compounds, primarily triazole derivatives, which might expand the temperature range of their application. We successfully demonstrated the feasibility of creating an HCI for $\mathrm{H}_{3} \mathrm{CCOOH}$ and $\mathrm{HCOOH}$ solutions by combining substituted triazoles with compounds of various classes [75] for the protection of steel 20 in these media at temperatures up to $100^{\circ} \mathrm{C}$. IFKhAN-92 alone poorly inhibits steel corrosion in $\mathrm{H}_{3} \mathrm{CCOOH}$ solutions, but its combinations with small amounts (10:1) of hydrophobic sulfur-containing compounds, which themselves are also weak CIs in this medium, protect steels very efficiently (Figure 4). The best mixture, $5.0 \mathrm{mM}$ IFKHAN-92+0.5 mM sodium diethyldithiocarbamate (DDTC), protects steel 20 in 2.0-6.0 $\mathrm{M} \mathrm{H}_{3} \mathrm{CCOOH}$ and $\mathrm{HCOOH}$ solutions at $20-100^{\circ} \mathrm{C}$ (Table 5, Figure 5). In the presence of this CI, the maximum values of $k$ for steel 20 in $\mathrm{H}_{3} \mathrm{CCOOH}$ and $\mathrm{HCOOH}$ solutions at $t \leq 100^{\circ} \mathrm{C}$ are 1.0 and $2.5 \mathrm{~g} /\left(\mathrm{m}^{2} \cdot \mathrm{h}\right)$, respectively. In the presence of the mixed CI, the $k$ of steel 20 remains low over time even at $t=100^{\circ} \mathrm{C}$. In both acids, a maximum of the corrosion inhibition coefficient of the CI in the $t$ range studied is not achieved. This indirectly indicates that efficient metal protection can be achieved even at higher $t$.

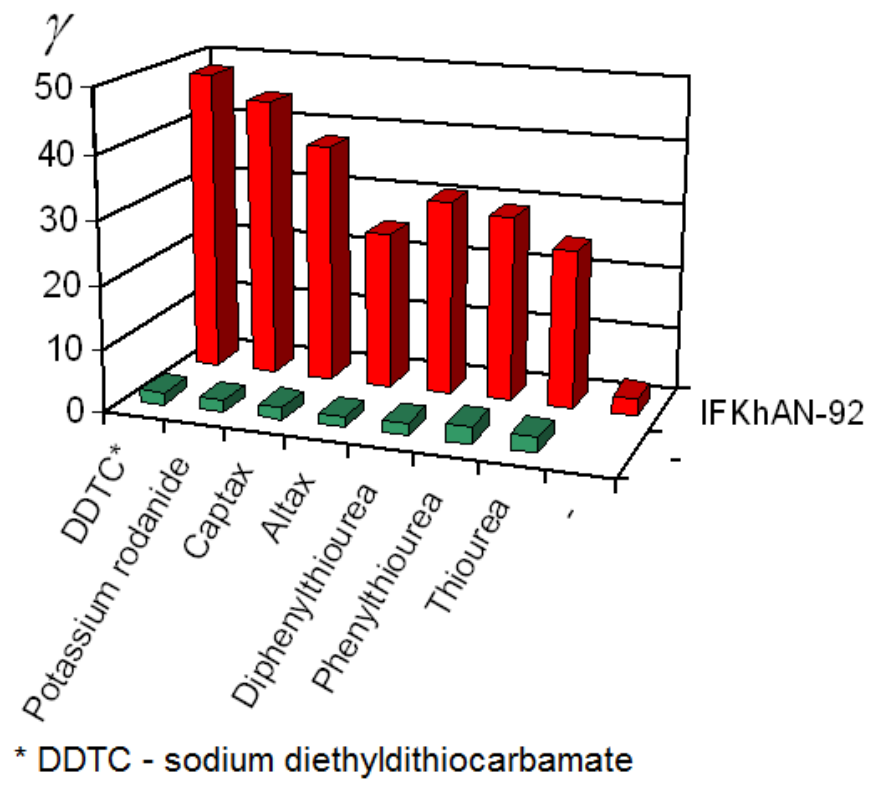

Figure 4. Steel corrosion inhibition factors for steel 20 in $4.0 \mathrm{M} \mathrm{H}_{3} \mathrm{CCOOH}\left(t=100^{\circ} \mathrm{C}\right)$ by sulphur-containing compounds $(0.5 \mathrm{mM})$ and their mixtures with 5.0 mM IFKhAN-92. Test duration $-2 \mathrm{~h}$. 
Table 5. Corrosion rates $\left(k, \mathrm{~g} /\left(\mathrm{m}^{2} \cdot \mathrm{h}\right)\right)$ and corrosion inhibition coefficients $(\gamma)$ of steel 20 in $\mathrm{H}_{3} \mathrm{CCOOH}$ and $\mathrm{HCOOH}$ solutions with addition of IFKhAN-92 + DDTC at $t=100^{\circ} \mathrm{C}$. Test duration $-2 \mathrm{~h}$.

\begin{tabular}{|c|c|c|c|c|c|c|}
\hline \multirow{3}{*}{ Inhibitor } & \multicolumn{6}{|c|}{ Acid concentration } \\
\hline & \multicolumn{2}{|c|}{$2.0 \mathrm{M}$} & \multicolumn{2}{|c|}{$4.0 \mathrm{M}$} & \multicolumn{2}{|c|}{ 6.0 M } \\
\hline & $k, \mathbf{g} /\left(\mathbf{m}^{2} \cdot \mathbf{h}\right)$ & $\gamma$ & $k, \mathbf{g} /\left(\mathbf{m}^{2} \cdot \mathbf{h}\right)$ & $\gamma$ & $k, \mathbf{g} /\left(\mathbf{m}^{2} \cdot \mathbf{h}\right)$ & $\gamma$ \\
\hline \multicolumn{7}{|c|}{$\mathrm{H}_{3} \mathrm{CCOOH}$} \\
\hline- & 31.7 & - & 48.1 & - & 42.9 & - \\
\hline $5.0 \mathrm{mM}$ IFKhAN-92 & 30.8 & 1.0 & 22.8 & 2.1 & 12.2 & 3.5 \\
\hline $0.5 \mathrm{mM}$ DDTC & 12.1 & 2.6 & 25.8 & 1.9 & 24.6 & 1.7 \\
\hline $\begin{array}{c}5.0 \mathrm{mM} \text { IFKhAN-92 }+0.5 \\
\text { mM DDTC }\end{array}$ & 0.81 & 39.1 & 1.0 & 48.1 & 0.89 & 48.2 \\
\hline \multicolumn{7}{|c|}{ НСООН } \\
\hline- & 109 & - & 185 & - & 226 & - \\
\hline $5.0 \mathrm{mM}$ IFKhAN-92 & 83.2 & 1.3 & 66.4 & 2.8 & 18.7 & 12.1 \\
\hline $0.5 \mathrm{mM}$ DDTC & 88.4 & 1.2 & 137 & 1.4 & 187 & 1.2 \\
\hline $\begin{array}{c}5.0 \mathrm{mM} \text { IFKhAN-92 }+0.5 \\
\text { mM DDTC }\end{array}$ & 1.1 & 99.1 & 2.5 & 74.0 & 1.3 & 174 \\
\hline
\end{tabular}

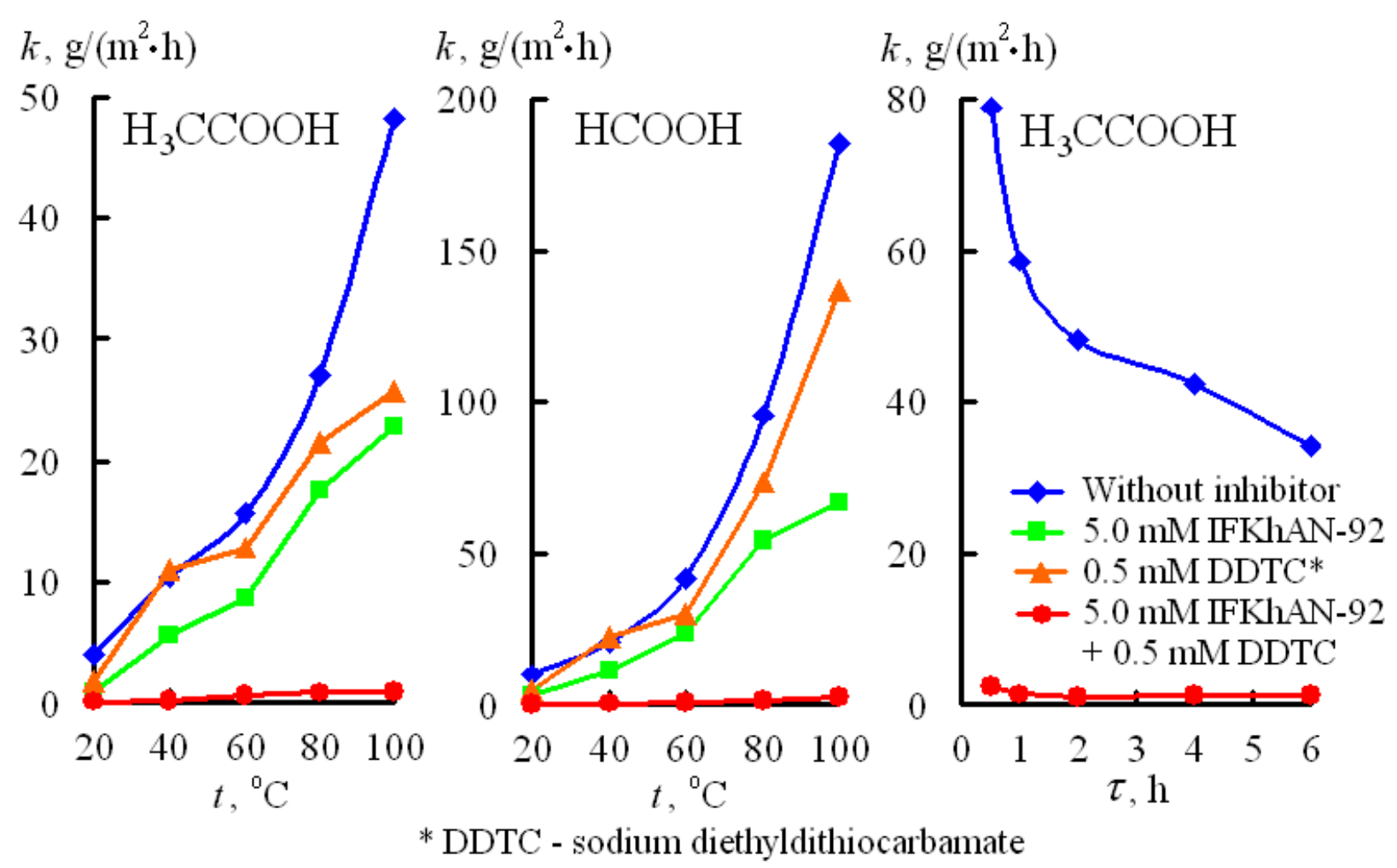

Figure 5. Corrosion rates of steel 20 in $4.0 \mathrm{M} \mathrm{H}_{3} \mathrm{CCOOH}$ and $4.0 \mathrm{M} \mathrm{HCOOH} . t=100^{\circ} \mathrm{C}$. 
The inhibition of steel corrosion in citric acid solutions has been studied insufficiently. To protect carbon steel in $4 \%$ citric acid, it was suggested to use 2-undecyl- $N$ carboxymethyl- $N$-hydroxyethyl imidazolium chloride $(0.4 \%)$ which, according to voltammetry data, decreases the $Z$ value from 89.2 to $84 \%$ upon a $t$ increase from 20 to $95^{\circ} \mathrm{C}$ [76]. Weak protection of cold rolled steel in $0.2 \mathrm{M}$ citric acid is provided by an extract of bamboo leaves, which is a "green CI" [77]. The effect of this CI strongly decreases with a $t$ increase to $50^{\circ} \mathrm{C}$. All the more interesting are the results on the protection of low-carbon steel in citric acid with a formulation of $4.5 \mathrm{mM}$ IFKhAN-92+0.5 mM KNCS [78]. At $95^{\circ} \mathrm{C}$, this $\mathrm{CI}$ formulation in $0.25-2.0 \mathrm{M}$ citric acid slows down the corrosion of steel $3\left(k_{0}=57.4-\right.$ $106 \mathrm{~g} /\left(\mathrm{m}^{2} \cdot \mathrm{h}\right)$ by a factor of 133-185. In inhibited media, the $k$ values of steel 3 are $k \leq 0.57 \mathrm{~g} /\left(\mathrm{m}^{2} \cdot \mathrm{h}\right)$. The maximum efficiency of the IFKhAN-92+KNCS mixture is not reached in the $t$ range studied.

Analysis of the results on the protection of steels in solutions of mineral acids by NHC derivatives shows that they have no prospects for this purpose in individual form. Even the most efficient of these CIs, i.e., triazole derivatives, lose their protective capability rather quickly at $t>100^{\circ} \mathrm{C}$. The best results in the protection of steels in acid environments can be obtained using mixed CIs based on NHC derivatives. The NHC derivatives used as the basis should contain a triazole ring. The triazole ring should be modified with various substituents that contain neither $\mathrm{C}=\mathrm{C}$ nor $\mathrm{C} \equiv \mathrm{C}$ bonds. Otherwise, the thermal stability of the $\mathrm{CI}$ in hot acid solutions will decrease and they will suffer many drawbacks typical of unsaturated organic CIs as we discussed in the second part of this review [1].

The protective effect of NHC derivatives on the corrosion of steels in mineral acid solutions can be enhanced and the temperature range of their efficiency can be expanded by combining these compounds with components of various nature. Urotropine is a versatile additive that improves the protective effect of $\mathrm{NHC}$ in $\mathrm{HCl}$ solutions. It is well compatible with pyridine derivatives (catapin A and I-1-A), but more interesting results can be obtained by using its combinations with substituted triazoles. In fact, a mixture of IFKhAN-92 and urotropine protects low-carbon steel in this environment up to $t=160^{\circ} \mathrm{C}$. It is interesting that efficient protection of the metal with a mixture of IFKhAN-92 and urotropine, especially at high $t$, requires urotropine to be the main component, though it is significantly inferior to IFKhAN-92 in the inhibitive effect. Binary mixtures of IFKhAN-92 with alkali metal iodides or bromides make it possible to protect low-carbon steels in sulfuric acid environments up to $t=200^{\circ} \mathrm{C}$. Alkali metal halides are widely used to enhance the action of organic CIs of various nature in acids [79], but only their combinations with triazoles make it possible to achieve such a good result. In solutions of $\mathrm{H}_{3} \mathrm{PO}_{4}$ and organic acids, where individual IFKhAN-92 is not a very efficient CI of steel, its effect can be improved considerably by combining it with relatively hydrophobic sulfur-containing compounds of molecular or anionic nature. The best results are provided by compounds of anionic nature, viz., KNCS and sodium diethyldithiocarbamate (DDTC).

Three-component formulations of triazole derivatives open wider prospects for the protection of steels in high-temperature acid solutions. The IFKhAN-92 + KI + urotropine 
mixture is a versatile CI that inhibits the corrosion of not only low-carbon steels but also chromium-nickel stainless steels that are very difficult for inhibitor protection. Threecomponent CIs containing a triazole derivative and urotropine are new and promising CIs of steels in highly corrosive acid media. As a rule, it is impossible to provide efficient protection of steels in mineral acid solutions containing an additional oxidizing agent, namely, $\mathrm{Fe}(\mathrm{III})$ salts $[48,80]$. The combination of IFKhAN-92, urotropine and KNCS makes it possible to protect low-carbon steels in such environments at $t \leq 80^{\circ} \mathrm{C}$, which is a unique result [81, 82].

The successful application of composite CIs based on NHCs for the protection of steels in high-temperature acid solutions makes the mechanism of their action an urgent question. Understanding its features for these CIs is not only important for their practical use but also opens a way for creating more efficient new HCIs.

\section{Mechanism of the protective action of nitrogen-containing heterocyclic organic compounds}

When the mechanism of the protective action of UCs was discussed [1], we noted that the protection of steels in high-temperature acid solutions can be provided only by those compounds which are chemically adsorbed on the metal surface and then form a polymolecular layer in which CI molecules are bound to each other by chemical bonds, on top of the chemisorbed inhibitor monolayer. In the case of UCs, the possibility of their adsorption on a steel surface and formation of a polymolecular protective film is provided by the presence of unsaturated $\mathrm{C} \equiv \mathrm{C}$ and $\mathrm{C}=\mathrm{C}$ bonds in their structure. In NHC derivatives, a nitrogen-containing heterocycle will serve as such an active site. As discussed above and based on experimental data on the protection of steels in high-temperature acid solutions, it is most promising to use a triazole as such an active center. The thermal stability of NHC derivatives in high-temperature acid solutions is extremely important. Otherwise, the CI will undergo destruction in a corrosive environment and will be removed from it. This condition is clearly confirmed by a study on the thermal stability of IFKhAN-92 that protects steels at $t \leq 200^{\circ} \mathrm{C}$. Optical spectrophotometry data for IFKhAN-92 solutions in $2 \mathrm{M} \mathrm{H}_{2} \mathrm{SO}_{4}$ $\left(t \leq 200^{\circ} \mathrm{C}\right)$ after exposure for $2 \mathrm{~h}$ show that the changes in the IR spectrum begin at $t=180^{\circ} \mathrm{C}$, indicating its stability at lower temperatures [83]. The intensity of the characteristic signal of IFKhAN-92 decreases by only $7 \%$ at $180^{\circ} \mathrm{C}$ and by $15 \%$ at $200^{\circ} \mathrm{C}$ in $2 \mathrm{~h}$. Note that the resinification of ACs, the well-known HCIs, begins at lower temperatures [84, 85]. In $4 \mathrm{M}$ $\mathrm{HCl}\left(150^{\circ} \mathrm{C}\right)$ in $3 \mathrm{~h}$, propargyl alcohol turns into a resinous product in $52 \%$ yield, while propargyl chloride does so in $70 \%$ yield.

The chemisorption interaction of a CI with a steel surface is a prerequisite that allows the CI to protect the metal under high-temperature corrosion conditions. This statement is clearly demonstrated by recent studies. It is believed that if the standard free adsorption energy of a CI $\left(-\Delta G_{\text {ads }}\right)$ is less than $20 \mathrm{~kJ} / \mathrm{mol}$, then physical adsorption takes place. Only if $\left(-\Delta G_{\text {ads }}\right) \geq 40 \mathrm{~kJ} / \mathrm{mol}$, one can state with high probability that the $\mathrm{CI}$ is chemisorbed. The $\left(-\Delta G_{\text {ads }}\right)$ value of 2-[(E)-[5-methoxy-1-[4-(trifluoromethyl)phenyl]pentylidene]amino]- 
oxyethanamine on mild steel in $1 \mathrm{M} \mathrm{HCl}$ is $15.2-21.4 \mathrm{~kJ} / \mathrm{mol}$, which indicates the physical nature of the interaction of the CI molecules with the metal surface. In the presence of $0.1 \mathrm{mM}$ of this $\mathrm{CI}$, an increase in $t$ from 30 to $60^{\circ} \mathrm{C}$ increases $Z$ from 94.4 to $95.1 \%$, but a further increase in $t$ decreases $Z$. At $90^{\circ} \mathrm{C}, Z=88.5 \%$ [86]. Most likely, the physically adsorbed CI molecules are desorbed at $t>60^{\circ} \mathrm{C}$, which impairs the metal protection. The maximum efficiency of this CI lies at $t=60^{\circ} \mathrm{C}$, so we cannot consider it as an HCI. A similar result is observed for 2-methyl-9-phenyl-1,2,3,4-tetrahydroacridine and ethyl 9-phenyl1,2,3,4-tetrahydroacridine-2-carboxylate whose $\left(-\Delta G_{\text {ads }}\right)$ is slightly higher and amounts to $25.4-30.6 \mathrm{~kJ} / \mathrm{mol}$. On X80 steel in $15 \% \mathrm{HCl}$, both CIs $(400 \mathrm{ppm})$ provide $Z=96.1$ and $94.4 \%$ at $30^{\circ} \mathrm{C}$, as well as 82.3 and $79.0 \%$ at $90^{\circ} \mathrm{C}$, respectively [87]. The results of these studies that are rare due to the wide temperature range they cover show that the absence of a chemical bond between the CI molecules and the metal surface does not allow the CI to provide efficient protection of steels in hot acid solutions.

To understand the nature of the NHC interaction with steel surfaces in acid solutions, the data on their $\left(-\Delta G_{\text {ads }}\right)$ require systematization. Though the literature available to us contains almost no estimates of NHC adsorption on steel from acid solutions by direct methods, there is plenty of data on the determination of $\left(-\Delta G_{\text {ads }}\right)$ obtained by a less correct method, viz., from the results of measuring the mass loss of steel samples in inhibited acid solutions.

Generalization and analysis of the data on the adsorption of six-membered NHCs on steels in acid media showed that in most cases the observed values of $\left(-\Delta G_{\text {ads }}\right)$ are insufficient to make an unambiguous conclusion about their chemisorption on a steel surface [6]. This is consistent with the conclusion made above that these compounds are unsuitable as a basis for creating HCIs.

Azole derivatives show more encouraging results. According to the data summarized in review [88], the values of $\left(-\Delta G_{\text {ads }}\right)$ for various imidazo[1,2- $a$ ]pyridines on steels in acid solutions are close to or higher than $40 \mathrm{~kJ} / \mathrm{mol}$, which allows us to hope that they are chemisorbed on the metals. Our analysis of literature data (Table 6) shows that for some derivatives of imidazoles, triazoles, and tetrazoles, the calculated values of $\left(-\Delta G_{\text {ads }}\right)$ reach or exceed the threshold value of $40 \mathrm{~kJ} / \mathrm{mol}$, which allows one to assume that the azoles are chemisorbed on steel. The data on the adsorption of azoles on steel measured by direct methods, i.e., by a decrease in the capacitance of the double electric layer (DEL) of a steel electrode obtained using the electrochemical impedance spectroscopy (EIS) and by ellipsometry, become even more valuable in this context.

An EIS study of the adsorption of the IFKhAN-92 HCI indicates the chemisorption nature of the interaction between the molecules of this CI and the steel surface. At $t=22^{\circ} \mathrm{C}$, the adsorption of IFKhAN-92 on cathodically polarized low-carbon steel is described by the Temkin isotherm, while $\left(-\Delta G_{\text {ads }}\right)$ is $42 \mathrm{~kJ} / \mathrm{mol}$ in $2.0 \mathrm{M} \mathrm{HCl} \mathrm{[102],} 49 \mathrm{~kJ} / \mathrm{mol}$ in $2.0 \mathrm{M}$ $\mathrm{H}_{2} \mathrm{SO}_{4}$ [103], and $51 \mathrm{~kJ} / \mathrm{mol}$ in $2.0 \mathrm{M} \mathrm{H}_{3} \mathrm{PO}_{4}$ [104]. It is important to note that the kinetics of IFKhAN-92 adsorption on low-carbon steel from solutions of mineral acids is described 
by the Roginsky-Zeldovich equation that characterizes chemisorption processes. As discussed earlier, IFKhAN-92 is inefficient in the protection of steels in $2.0 \mathrm{M} \mathrm{H}_{3} \mathrm{PO}_{4}$, but its combination with $0.5 \mathrm{mM} \mathrm{KNCS}$ can improve protection considerably. It was shown that addition of KNCS to $2.0 \mathrm{M} \mathrm{H}_{3} \mathrm{PO}_{4}$ does not affect the value of $\left(-\Delta G_{\text {ads }}\right)$ of IFKhAN-92 on steel but accelerates its adsorption, as the kinetic adsorption isotherms clearly demonstrate (Figure 6) [104]. Apparently, this effect favors the accelerated formation of a protective CI layer on the metal surface that rapidly degrades in acid solutions, this providing the required protection. It should be noted that this is just one of the possible ways in which the KNCS additive can affect a corroding system.

Table 6. Free adsorption energies of substituted azoles on steels from acid media.

\begin{tabular}{|c|c|c|c|c|c|}
\hline No. & Inhibitor & System & $\begin{array}{c}\text { Standard } \\
\text { adsorption free } \\
\text { energy }\left(-\Delta G_{\text {ads }}\right), \\
\mathbf{k J} / \mathbf{m o l}\end{array}$ & $\begin{array}{l}\text { Adsorption } \\
\text { isotherm }\end{array}$ & Ref. \\
\hline \multicolumn{6}{|c|}{ Imidazoles } \\
\hline 1 & $\begin{array}{l}\text { 2-(2-Methyl-5-nitro-1H-imidazol- } \\
\text { 1-yl)ethanol] }\end{array}$ & $\begin{array}{c}0.5 \mathrm{M} \mathrm{HCl} \\
\left(30-60^{\circ} \mathrm{C}\right) . \\
\text { Mild steel }\end{array}$ & $58.2-66.0$ & $\begin{array}{c}\text { Temkin } \\
\text { isotherm }\end{array}$ & [89] \\
\hline 2 & $\begin{array}{l}\text { 5-((4,5-Dihydro-imidazol-2-yl) } \\
\text { methyl)quinolin-8-ol }\end{array}$ & $\begin{array}{c}1 \mathrm{M} \mathrm{HCl} \\
\left(25^{\circ} \mathrm{C}\right) . \text { Mild } \\
\text { steel }\end{array}$ & 40.3 & $\begin{array}{l}\text { Langmuir } \\
\text { isotherm }\end{array}$ & [90] \\
\hline 3 & $\begin{array}{c}\text { 2-(3-(Carboxymethyl)- } 1 H \text { - } \\
\text { imidazol-3-ium-1-yl)acetate, } \\
\text { 2-(3-(1-carboxyethyl)-1H- } \\
\text { imidazol-3-ium-1-yl)propanoate, } \\
\text { 2-(3-(1-carboxy-2-phenylethyl)- } \\
\text { 1H-imidazol-3-ium-1-yl)-3- } \\
\text { phenylpropanoate }\end{array}$ & $\begin{array}{c}1 \mathrm{M} \mathrm{HCl} \\
\left(35^{\circ} \mathrm{C}\right) . \text { Mild } \\
\text { steel }\end{array}$ & $\begin{array}{l}37.5 . \\
37.6\end{array}$ & $\begin{array}{l}\text { Langmuir } \\
\text { isotherm }\end{array}$ & [91] \\
\hline 4 & $\begin{array}{c}\text { 2-(4-Chlorophenyl)-1,4,5- } \\
\text { triphenyl-1H-imidazole, } \\
\text { 1,4,5-triphenyl-2-(p-tolyl)-1H- } \\
\text { imidazole }\end{array}$ & $\begin{array}{c}0.5 \mathrm{M} \mathrm{H}_{2} \mathrm{SO}_{4} \\
\left(25^{\circ} \mathrm{C}\right) . \\
\text { Mild steel }\end{array}$ & $\begin{array}{l}42.1 . \\
41.7\end{array}$ & $\begin{array}{l}\text { Langmuir } \\
\text { isotherm }\end{array}$ & [92] \\
\hline 5 & $\begin{array}{l}\text { 1,3-Dioctadecylimidazolium } \\
\text { bromide }\end{array}$ & $\begin{array}{c}1 \mathrm{M} \mathrm{H}_{2} \mathrm{SO}_{4} \\
(\text { room } t) \text {. Mild } \\
\text { steel SAE } 1018\end{array}$ & 37.9 & $\begin{array}{l}\text { Langmuir } \\
\text { isotherm }\end{array}$ & [93] \\
\hline
\end{tabular}




\begin{tabular}{|c|c|c|c|c|c|}
\hline No. & Inhibitor & System & $\begin{array}{c}\text { Standard } \\
\text { adsorption free } \\
\text { energy }\left(-\Delta G_{\text {ads }}\right), \\
\mathbf{k J} / \mathbf{m o l}\end{array}$ & $\begin{array}{l}\text { Adsorption } \\
\text { isotherm }\end{array}$ & Ref. \\
\hline \multicolumn{6}{|c|}{ Triazoles } \\
\hline 6 & $\begin{array}{l}\text { 3,5-Bis(methylene octadecyl } \\
\text { dimethylammonium chloride)- } \\
\text { 1,2,4-triazole }\end{array}$ & $\begin{array}{c}1 \mathrm{M} \mathrm{HCl} \\
\left(25^{\circ} \mathrm{C}\right) \\
\text { Carbon steel }\end{array}$ & 42.1 & $\begin{array}{l}\text { Langmuir } \\
\text { isotherm }\end{array}$ & [94] \\
\hline 7 & $\begin{array}{l}\text { 3,5-Bis(4-pyridyl)-4H-1,2,4- } \\
\text { triazole, } \\
\text { 3,5-bis(4-methylthiophenyl)-4H- } \\
\text { 1,2,4-triazole }\end{array}$ & $\begin{array}{l}1 \mathrm{M} \mathrm{HCl} \\
\left(30^{\circ} \mathrm{C}\right) . \\
\text { Mild steel }\end{array}$ & $\begin{array}{l}39.4 \\
44.4\end{array}$ & $\begin{array}{l}\text { Langmuir } \\
\text { isotherm }\end{array}$ & [95] \\
\hline 8 & $\begin{array}{l}\text { 3,5-Bis(2-thienylmethyl)-4- } \\
\text { amino-1,2,4-triazole }\end{array}$ & $\begin{array}{c}1 \mathrm{M} \mathrm{HCl} \\
\left(30^{\circ} \mathrm{C}\right) . \\
\text { Carbon steel }\end{array}$ & 45.7 & $\begin{array}{l}\text { Langmuir } \\
\text { isotherm }\end{array}$ & [96] \\
\hline 9 & $\begin{array}{l}\text { 3,5-Bis(4-methoxyphenyl)-4- } \\
\text { amino-1,2,4-triazole, } \\
\text { 3,5-bis(4-chlorophenyl)-4-amino- } \\
\text { 1,2,4-triazole }\end{array}$ & $\begin{array}{l}2 \mathrm{M} \mathrm{H}_{3} \mathrm{PO}_{4} \\
\left(30^{\circ} \mathrm{C}\right) \\
\text { mild steel }\end{array}$ & $\begin{array}{l}41.1 \\
39.8\end{array}$ & $\begin{array}{l}\text { Langmuir } \\
\text { isotherm }\end{array}$ & [97] \\
\hline 10 & $\begin{array}{l}\text { 3,5-Bis(4-tolyl)-4-amino-1,2,4- } \\
\text { triazole, } \\
\text { 3,5-Bis(3,4-dimethoxyphenyl)-4- } \\
\text { amino-1,2,4-triazole }\end{array}$ & $\begin{array}{l}2 \mathrm{M} \mathrm{H}_{3} \mathrm{PO}_{4} \\
\left(30^{\circ} \mathrm{C}\right) \\
\text { Mild steel }\end{array}$ & $\begin{array}{l}39.8 \\
40.0\end{array}$ & $\begin{array}{l}\text { Langmuir } \\
\text { isotherm }\end{array}$ & [98] \\
\hline \multicolumn{6}{|c|}{ Tetrazoles } \\
\hline 11 & $\begin{array}{l}\text { (E)-3-(4-Hydroxyphenyl)-2-(1H- } \\
\text { tetrazole-5-yl)acrylonitrile }\end{array}$ & $\begin{array}{c}1 \mathrm{M} \mathrm{HCl} \\
\left(35-65^{\circ} \mathrm{C}\right) \\
\text { Mild steel }\end{array}$ & $37.6-39.7$ & $\begin{array}{l}\text { Langmuir } \\
\text { isotherm }\end{array}$ & [99] \\
\hline 12 & $\begin{array}{l}\text { 2,2'-Bis(4-nitrophenyl)-5,5'- } \\
\text { diphenyl-3,3'-(3,3'-dimethoxy- } \\
\text { 4,4'-diphenylene)ditetrazolium } \\
\text { chloride }\end{array}$ & $\begin{array}{l}0.5 \mathrm{M} \mathrm{H}_{2} \mathrm{SO}_{4} \\
\left(25^{\circ} \mathrm{C}\right) \text {. Cold } \\
\text { rolled steel }\end{array}$ & 41 & $\begin{array}{l}\text { Langmuir } \\
\text { isotherm }\end{array}$ & {$[100]$} \\
\hline 13 & $\begin{array}{c}\text { 3,3'-(3,3'-Dimethoxy[1,1'- } \\
\text { biphenyl]-4,4'-diyl)-bis(2,5- } \\
\text { diphenyl-2H-tetrazolium) } \\
\text { dichloride }\end{array}$ & $\begin{array}{l}1.0 \mathrm{M} \mathrm{H}_{2} \mathrm{SO}_{4} \\
\left(20^{\circ} \mathrm{C}\right) . \text { Cold } \\
\text { rolled steel }\end{array}$ & 39.1 & $\begin{array}{l}\text { Langmuir } \\
\text { isotherm }\end{array}$ & [101] \\
\hline
\end{tabular}

The chemisorptive interaction of triazoles with a steel surface in acid media is characteristic not only of low-carbon steels but also of chromium-nickel ones that are very difficult to protect by inhibitors. In fact, the values of $\left(-\Delta G_{\text {ads }}\right)$ for IFKhAN-92 on $12 \mathrm{Kh} 18 \mathrm{~N} 10 \mathrm{~T}$ steel calculated using the Temkin equation amount to $55 \pm 1$ and $61 \pm 1 \mathrm{~kJ} / \mathrm{mol}$ 
for $2.0 \mathrm{M} \mathrm{HCl}$ and $2.0 \mathrm{M} \mathrm{H}_{2} \mathrm{SO}_{4}$, respectively [105]. This result is in good agreement with the data of an ellipsometric study on its adsorption, according to which the ( $\left.-\Delta G_{\text {ads }}\right)$ values on $12 \mathrm{Kh} 18 \mathrm{~N} 10 \mathrm{~T}$ steel in $0.005-0.05 \mathrm{M} \mathrm{HCl}$ and $0.05 \mathrm{M} \mathrm{H}_{2} \mathrm{SO}_{4}$ calculated from the Temkin isotherm are $55 \pm 3 \mathrm{~kJ} / \mathrm{mol}[106]$.

Important additional information on the nature of binding of CI molecules with a steel surface can be obtained using quantum chemical methods. In recent years, more and more studies were appearing in which quantum-chemical calculations were used to explain the inhibitory effect of azoles [107-113]. A detailed analysis of the prospects of using quantum chemical methods for explaining the inhibitory action of organic compounds, including azoles, was carried out in the review [114], so this issue can be left outside the scope of our review.

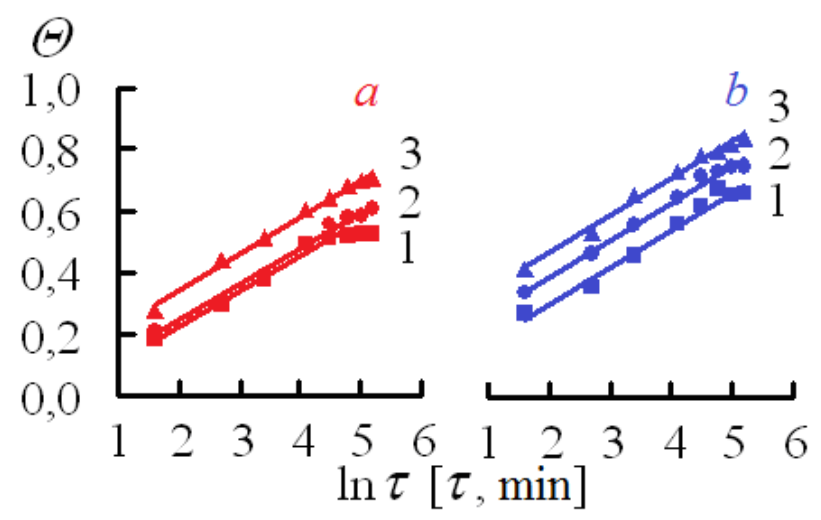

Figure 6. Dependence of the coverage of steel 3 surface with inhibitor $(E=-0.30 \mathrm{~V})$ on the logarithm of its adsorption time in $2 \mathrm{M} \mathrm{H}_{3} \mathrm{PO}_{4}\left(22^{\circ} \mathrm{C}\right)$ containing IFKhAN-92 $(a)$ and its combination with $0.5 \mathrm{mM}$ KNCS $(b)$, with concentrations in $\mu \mathrm{m}: 1-2.5,2-5.0,3-10$. Points - observed plots. Straight lines - theoretical plot for the Roginsky-Zeldovich equation.

To a considerable extent, the unique property of triazoles that gives them the ability to protect steels in high-temperature acid solutions is that they can form polymolecular protective layers from their molecules on the metal surface. X-Ray photoelectron spectroscopy (XPS) combined with argon ion etching of the object surface provides the most productive method for studying such surface layers. This XPS technique allows one to determine the qualitative and quantitative composition of not only the layers directly adjacent to its surface, but also the underlying sample layers that are inaccessible by ordinary methods. Our studies show that, according to XPS data, a $24 \mathrm{~h}$ exposure of steel 3 samples in $2.0 \mathrm{M} \mathrm{HCl}+5.0 \mathrm{mM}$ IFKhAN-92 $\left(20^{\circ} \mathrm{C}\right)$ results in the formation of a protective layer of the organic inhibitor $4 \mathrm{~nm}$ thick on the metal (no more than 4 monomolecular layers). Upon sixfold ultrasonic cleaning of the steel surface in distilled water ( 3 min each time), only a tentative inhibitor monolayer with a thickness of no more than $2 \mathrm{~nm}$ remains on the metal. The CI monolayer remaining on the steel surface at $t=20-60^{\circ} \mathrm{C}$ provides $Z=88.9-96.4 \%$. This value is slightly worse than that of the polymolecular CI layer $(Z=94.9-98.8 \%)$ but 
high enough to confirm the chemisorptive nature of the CI interaction with the steel surface (Figure 7a). Thus, a polymolecular protective CI layer is formed on steel in this medium. It consists of its monolayer chemisorbed on the metal, on top of which there are layers of CI molecules bound to each other and to the chemisorbed layer by weaker physical interaction. Ultrasonic cleaning removes the physically sorbed molecules from the steel surface, leaving only a chemisorbed monolayer. In this case, the metal surface underlying the organic CI layer is oxidized to iron(III) oxide. A CI layer similar in structure and protective properties is formed in 2.0 $\mathrm{M} \mathrm{H}_{2} \mathrm{SO}_{4}+5.0 \mathrm{mM}$ IFKhAN-92+5.0 mM KNCS (Figure 7b) but, despite the presence of KNCS in the inhibitor formulation, no thiocyanate anions are found in the protective layer [115]. Triazoles do not always form polymolecular layers on a metal being protected. In fact, IFKhAN-96 is adsorbed on steel surface from $2.0 \mathrm{M} \mathrm{HCl}\left(25^{\circ} \mathrm{C}\right)$ to form only a tentative $\mathrm{CI}$ monolayer chemically bound to the metal surface. Under a monolayer of the organic CI, there are phases of iron(II) chloride and oxide 4-7 nm thick that are directly adjacent to the metal [32].
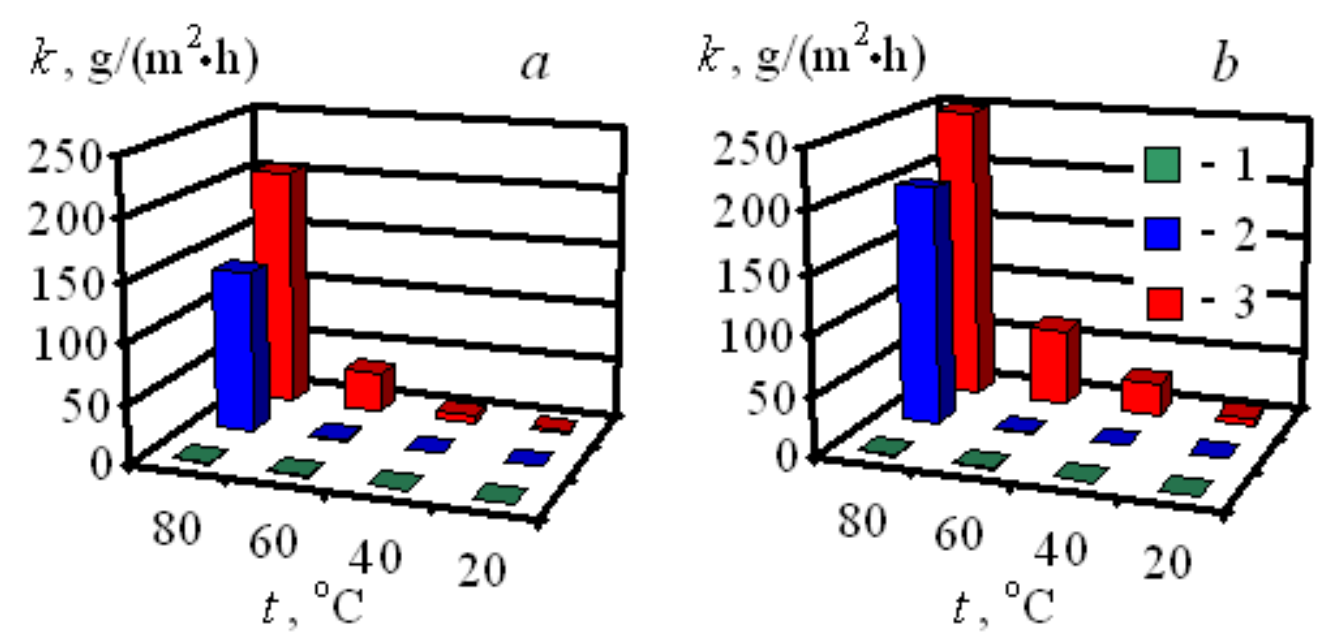

Figure 7. Protective after-effect of inhibitor layers formed at $t=20^{\circ} \mathrm{C}$ on the surface of steel 3 in $2 \mathrm{M} \mathrm{HCl}+5 \mathrm{mM}$ IFKhAN-92 $(a)$ and $2 \mathrm{M} \mathrm{H}_{2} \mathrm{SO}_{4}+5 \mathrm{mM}$ IFKhAN-92 + $5 \mathrm{mM}$ KNCS $(b)$ in $2 \mathrm{M} \mathrm{HCl}(a)$ and $2 \mathrm{M} \mathrm{H}_{2} \mathrm{SO}_{4}(b)$ solution $(2 \mathrm{~h})$. 1 - samples after preliminary inhibitor adsorption ( $24 \mathrm{~h}), 2$ - samples after preliminary inhibitor adsorption ( $24 \mathrm{~h}$ ) followed by ultrasonic washing, 3 - samples without preliminary inhibitor adsorption.

The protective layers formed by IFKhAN-92 in phosphoric acid solutions have more complex structures [116]. During preliminary adsorption of a IFKhAN-92+KNCS mixture on steel surface from $\mathrm{H}_{3} \mathrm{PO}_{4}$ solutions, a chemisorbed protective layer more than $4 \mathrm{~nm}$ thick is formed, which presumably consists of a complex polymeric compound of IFKhAN-92 molecules, Fe(II) cations, and rhodanide anions (Figure 8). This layer is not removed from the steel surface during ultrasonic treatment and has a protective aftereffect in hot $\mathrm{H}_{3} \mathrm{PO}_{4}$ solutions, as we discussed in our review [48]. One can see that addition of KNCS not only accelerates the adsorption of the triazole on steel but can also participate in the formation of a protective layer of the organic inhibitor. 


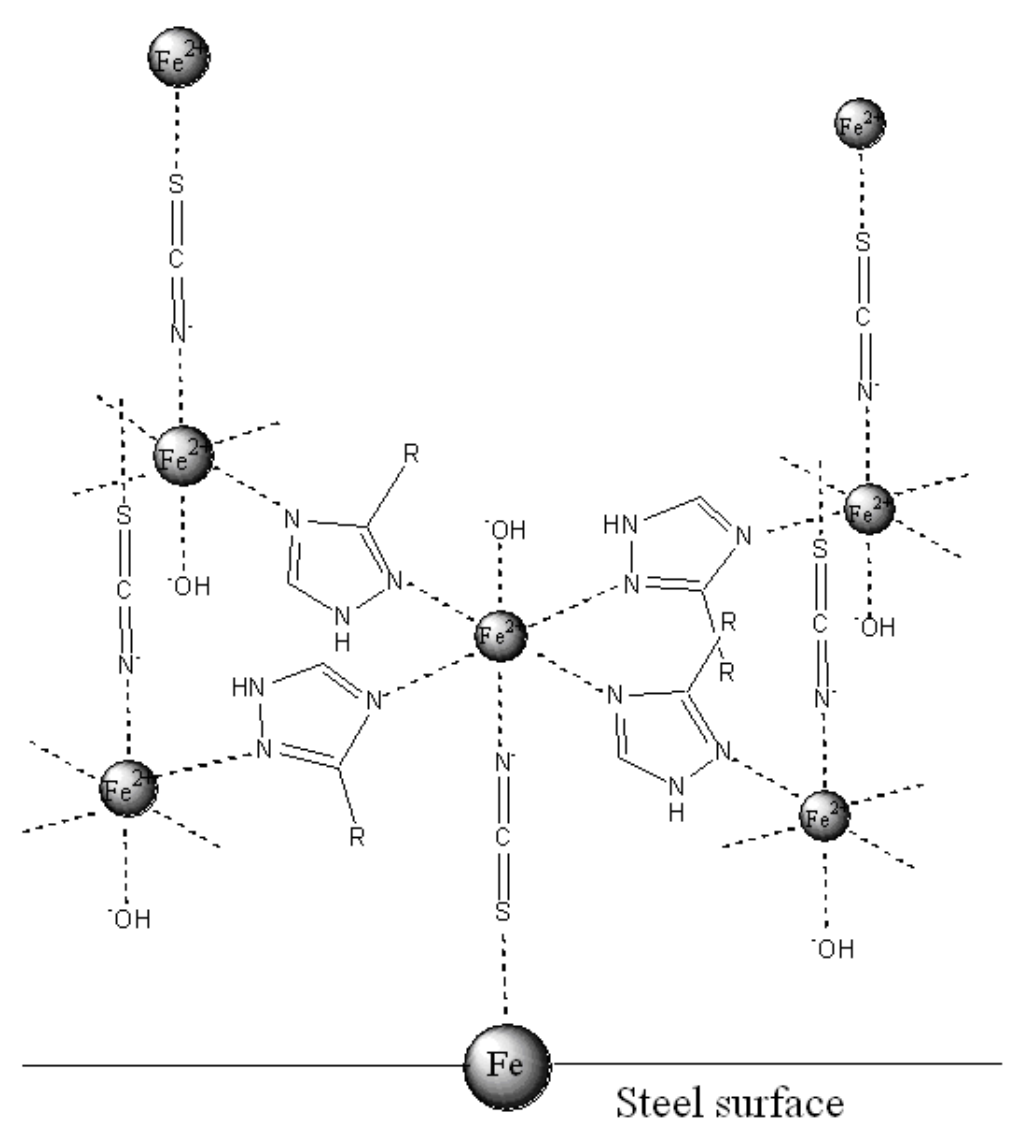

Figure 8. The assumed structure of the protective layer formed on steel 3 surface in $2 \mathrm{M}$ $\mathrm{H}_{3} \mathrm{PO}_{4}+5 \mathrm{mM}$ IFKhAN-92 $+5 \mathrm{mM} \mathrm{KNCS}\left(25^{\circ} \mathrm{C}\right)$.

Protective polymolecular layers of IFKhAN-92 are formed not only on low-carbon steel but also on chromium-nickel steels. During preliminary adsorption of IFKhAN-92 on the surface of 12Kh18N10T steel, a polymolecular protective organic CI layer is formed from an $\mathrm{HCl}$ solution. It is chemically bound to the phase of $\mathrm{Fe}, \mathrm{Cr}$ and $\mathrm{Ni}$ oxides and hydroxides adjacent to the metal phase $[117,118]$. The lower part of the polymolecular protective layer of the organic CI consists of a polymer complex formed by IFKhAN-92 molecules, metal cations ( $\mathrm{Fe}, \mathrm{Cr}$ and $\mathrm{Ni}$ ) and chloride anions, while the outer part consists of physically sorbed IFKhAN-92 molecules. Weakly bound CI layers are removed from the metal surface during its ultrasonic cleaning in an $\mathrm{HCl}$ solution. The $\mathrm{CI}$ layer remaining on the metal surface (about 3 monolayers) exhibits a protective aftereffect in $2 \mathrm{M} \mathrm{HCl}$ with $t$ up to $80^{\circ} \mathrm{C}$ (Figure 9), which is evidence of the chemical nature of interaction of the organic CI within the layer of its complex polymer with the surface of the oxide-hydroxide phase. We noted the formation of structurally similar protective layers on chromium-nickel steels in case of its protection in $\mathrm{H}_{2} \mathrm{SO}_{4}$ solutions with composite CIs based on IFKhAN-92 [119].

Thus, an important property of triazole derivatives as CIs of steels in acid solutions is their ability to form polymolecular protective layers on a metal surface. A specific feature of these layers is that the underlying CI layer is chemically bound to the steel surface. Above this layer, there are layers of the organic CI whose molecules are bound either physically or 
chemically with each other. It is clear that the maximum protective effects will be provided by chemically bound CI layers. Experimental data indicate that organic CI layers consist of a polymer complex of triazole molecules and $\mathrm{Fe}$ cations $(\mathrm{Cr}$ and $\mathrm{Ni}$ in the case of chromiumnickel steels). In addition, the components of the triazole-based CI mixture (for example, thiocyanate anion) can be incorporated into the structure of the polymer complex, which ultimately strengthens the complex structure. It is the formation of such polymolecular layers that allows triazoles to provide efficient protection of steels in high-temperature acid solutions.

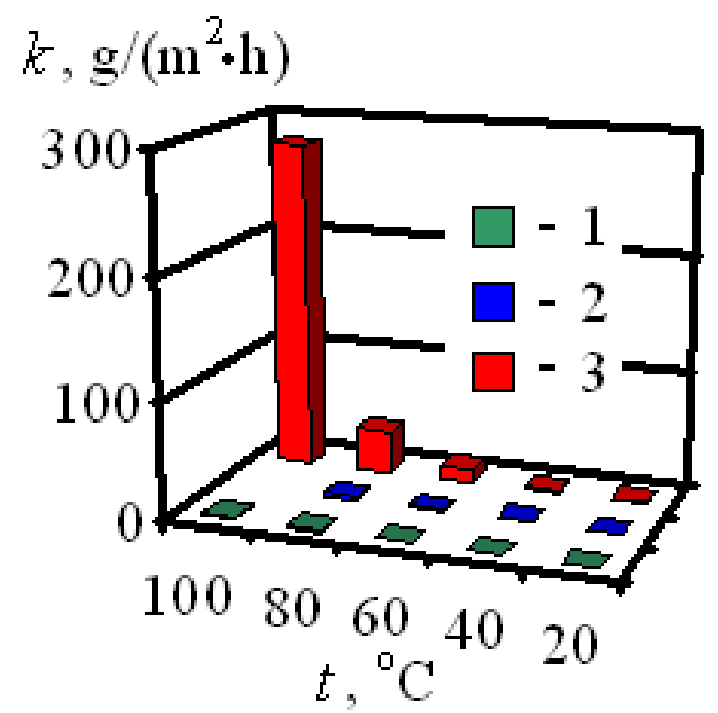

Figure 9. Protective after-effect of inhibitor layers formed on the surface of chromium-nickel steel $12 \mathrm{Kh} 18 \mathrm{~N} 10 \mathrm{~T}$ in $2 \mathrm{M} \mathrm{HCl}+5 \mathrm{mM}$ IFKhAN-92 $\left(20^{\circ} \mathrm{C}\right)$ in $2 \mathrm{M} \mathrm{HCl}$ solution $(2 \mathrm{~h})$. 1 - samples after preliminary inhibitor adsorption $(24 \mathrm{~h}), 2$ - samples after preliminary inhibitor adsorption ( $24 \mathrm{~h}$ ) followed by ultrasonic washing, 3 - samples without preliminary inhibitor adsorption.

Let us consider the possible reasons for the improvement of the protective effect of HCIs upon addition of urotropine. This issue was not studied separately, but XPS data indicate that the combination of IFKhAN-92 with urotropine seals the protective layer formed on the surface of $12 \mathrm{Kh} 18 \mathrm{~N} 10 \mathrm{~T}$ steel in $\mathrm{HCl}$ solution, presumably due to chemical crosslinking of the organic parts of CI molecules initiated by formaldehyde, a product of urotropine hydrolysis [117]. In general, this issue requires a more detailed experimental study, considering the practical importance of HCIs that contain urotropine.

Literature sources provide extensive data on the electrochemical behavior of triazoles in acid solutions at temperatures that rarely reach $75^{\circ} \mathrm{C}$ [120-129]. Voltammetric measurements indicate that these compounds efficiently inhibit the cathodic and anodic reactions that occur on steels. According to EIS results, addition of such CIs into a corrosive environment decreases the capacitance of the double electric layer on steel and increases the polarization resistance. Voltammetry and EIS data are always in good agreement with the $k$ of steel samples obtained by measuring their mass loss. In view of this, data related to higher 
temperatures become even more interesting. Using IFKhAN-92 as an example, it has been shown that individual triazoles or formulations based on them can significantly slow down the electrode reactions on low-carbon [130] and chromium-nickel [41, 42] steels in $\mathrm{HCl}$ and $\mathrm{H}_{2} \mathrm{SO}_{4}$ solutions at temperatures close to $100^{\circ} \mathrm{C}$.

Formulations of IFKhAN-92 with sulfur-containing compounds have a similar effect on the electrode reactions on low-carbon steel in solutions of $\mathrm{H}_{3} \mathrm{PO}_{4}$ [131], acetic, formic [75] and citric [78] acids. In particular, the addition of 5.0 mM IFKhAN-92+0.5 mM DDTC significantly inhibits the electrode reactions of steel 3 in $4.0 \mathrm{M} \mathrm{H}_{3} \mathrm{CCOOH}$ and $4.0 \mathrm{M}$ $\mathrm{HCOOH}\left(t=100^{\circ} \mathrm{C}\right)$, though the individual components of the mixed CI do not affect these reactions considerably (Figure 10). These results are in good agreement with the data of corrosion tests (Table 5) based on the weight loss of metal samples, according to which the IFKHAN-92+DDTC formulation significantly slows down the corrosion of steel 3 in both acids under these conditions [75].

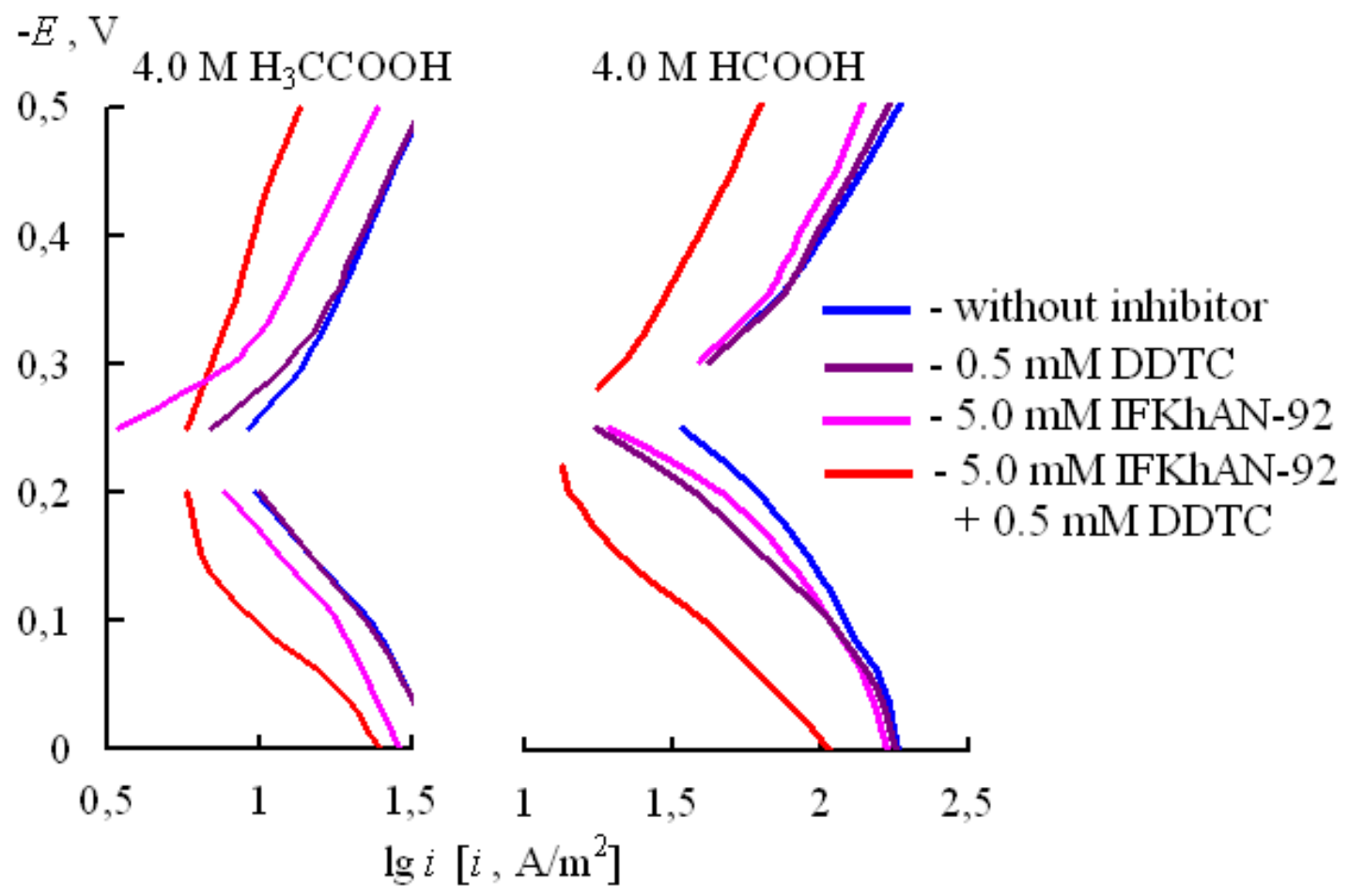

Figure 10. Polarization curves of steel 3 in acetic and formic acids $\left(t=100^{\circ} \mathrm{C}\right)$ with addition of 5.0 mM IFKhAN-92 + 0.5 mM DDTC.

The high protective effects of IFKhAN-92 and its formulations in inhibiting the electrode reaction of steel at temperatures close to $100^{\circ} \mathrm{C}$ allow us to hope that they will retain their protective effect even at higher temperatures. Thus, the layers formed by triazoles on a steel surface can slow down both electrode reactions on the metal in a wide temperature range, which ultimately determines the possibility of its protection even under hightemperature corrosion conditions. 


\section{Protection of chromium-nickel steels in phosphoric acid solutions by inorganic inhibitors}

In exceptional cases, steels can be protected in high-temperature acid solutions by inorganic CIs alone. It is known that chromium-nickel steel Kh18N10T is in an unstable passive state in $1-10 \mathrm{M} \mathrm{H}_{3} \mathrm{PO}_{4}$ at $t=100-150^{\circ} \mathrm{C}$, so that a few similar samples exposed to a totally identical corrosive environment are destroyed at rates that differ by more than an order of magnitude. In these cases, the maximum corrosion rate $(k)$ of the samples reaches tens of $\mathrm{g} /\left(\mathrm{m}^{2} \cdot \mathrm{h}\right)$. For example, in $3 \mathrm{M} \mathrm{H}_{3} \mathrm{PO}_{4}\left(130^{\circ} \mathrm{C}\right)$ the $k$ values of steel vary within 0.085 to $7.5 \mathrm{~g} /\left(\mathrm{m}^{2} \cdot \mathrm{h}\right)[132,133]$. In the industrial operation of a metal, such a behavior can cause unpredictable and spontaneous destruction of structures, which is unacceptable, especially where such hazardous process fluids as hot acids are used.

It is recommended to add $\mathrm{Cu}$ (II) cations obtained by dissolving $\mathrm{CuO}$ in $\mathrm{H}_{3} \mathrm{PO}_{4}$, or $\mathrm{NO}_{3}^{-}$ anions in the form of $\mathrm{NaNO}_{3}$ for the protection of Kh18N10T steel in hot $\mathrm{H}_{3} \mathrm{PO}_{4}$ solutions (up to $130^{\circ} \mathrm{C}$ ). The mechanism of action of these additives that favor the preservation of the stable passive state of chromium-nickel steel in $\mathrm{H}_{3} \mathrm{PO}_{4}$ solutions was considered. It was shown that $\mathrm{Cu}$ (II) ions inhibit the anodic reaction of steel dissolution in the active state. The inhibiting effect of $\mathrm{Cu}$ (II) cations becomes even stronger in the presence of nitrate ions, up to complete suppression of the anodic reaction. The synergistic effect is explained by a change in the structure of metallic copper precipitated from a solution in the presence of nitrate ions. It has also been found that copper ions catalyze the nitrate reduction reaction. The activating effect is attributed to $\mathrm{Cu}(\mathrm{I})$ ions that are formed as an intermediate product in the chemical reduction of $\mathrm{Cu}$ (II) cations. $\mathrm{Cu}$ (I) ions chemically react with nitrate to give reactive components which, unlike nitrates, can be easily discharged on the cathode, thus increasing the efficiency of the overall cathodic process and promoting the electrode passivation [134-137].

The protection of steel structures with inorganic compounds in high-temperature acid solutions is possible only if the metal being protected is already in the passive region. In the media we are discussing, this state can be observed in the case of high-alloy steels. The passive state of steels in acid environments can be preserved by oxidizing agents. This study clearly shows that the use of oxidizing-type CIs (nitrate ion, $\mathrm{Cu}(\mathrm{II})$ ) makes it possible to protect steels in hot acid solutions.

\section{Conclusions}

Based on the concept of the mechanism of acid corrosion inhibition by UCs and NHCs, let us formulate the basic principles of inhibitory protection of metals in mineral acids at $t>100^{\circ} \mathrm{C}$. Under high temperature acid corrosion conditions, it is only possible if the CI forms a protective film on the metal surface that is firmly bound to it. A protective film on a metal can be formed by addition to the corrosive environment of monomeric UCs that can polymerize upon adsorption on the metal surface. Such polymerization can decrease the solubility of the adsorbed layer, increase the protective effect, and make the adsorption 
irreversible. However, UCs are prone to side polymerization reactions in the bulk of the corrosive medium, which is extremely undesirable in practical use [1].

A fundamentally new and more promising method to create protective coatings on steels is to use thermostable azoles. These compounds are chemisorbed on the metal surface and form a monomolecular layer firmly bound to its surface. On top of this layer, additional polymolecular physical or chemical adsorption of the CI occurs, which significantly improves its protective properties. An important way to increase the efficiency of azoles and expand their temperature range of application is to create synergistic formulations based on them.

Thus, a high-temperature CI of steels in acid solutions should:

- be capable of strong adsorption on the corroding metal surface;

- form a polymolecular protective layer on the metal in order to provide the strongest protection;

- be thermally stable in acid solutions (without resinification);

- enhance the protective effect under high-temperature conditions when combined with other thermally stable additives.

Triazole derivatives that fully comply with the requirements listed above should be used as a basis for creating mixed HCIs based on NHCs. Diazoles and tetrazoles can become an alternative to triazoles, but the possibility of their use as HCIs needs to be checked by experiments. It should be borne in mind that the industrial use of UCs, pyridine and quinoline derivatives and additives compatible with them as CIs [1] will be limited by the environmental requirements for such compounds. In view of this, triazole derivatives are more interesting. To create HCIs, they should be combined with safe and cheap urotropine, as well as relatively safe alkali metal iodides and bromides as additives. The use of mixed CIs based on UCs is well justified only for hydrochloric acid solutions. Composite CIs based on triazoles are more versatile. They can be used to protect steels both in mineral $(\mathrm{HCl}$, $\mathrm{H}_{2} \mathrm{SO}_{4}, \mathrm{H}_{3} \mathrm{PO}_{4}$ ) and organic (acetic, formic, citric) acids.

To summarize, the authors of the review express their hope that the results they collected concerning the inhibitory protection of steels in high-temperature acid solutions will be interesting and useful to the readers. The regularities of the inhibitory protection of steels in high-temperature acid solutions that we discussed open the possible approaches to the creation of new HCIs urgently required by the oil and gas industry and by metallurgical industry.

\section{Acknowledgements}

This study was carried out within the framework of the Program of Basic Scientific Research of the State Academies of Sciences for 2013-2020, topic "Development of the fundamental scientific basis of the protective effect of inhibitors of metal corrosion in gas and condensed media, nanocomposites, paintwork and conversion coatings" (state registration number AAAA-A18-118121090043-0). 


\section{References}

1. Ya.G. Avdeev and Yu.I.Kuznetsov, Inhibitory protection of steels from hightemperature corrosion in acid solutions. A review. Part 2., Int. J. Corros. Scale Inhib., 2020, 9, no. 3, 867-902. doi: 10.17675/2305-6894-2020-9-3-5

2. M. Finšgar and J. Jackson, Application of corrosion inhibitors for steels in acidic media for the oil and gas industry: A review, Corros. Sci., 2014, 86, 17-41. doi: 10.1016/j.corsci.2014.04.044

3. K.R. Ansari, D.S. Chauhan, A. Singh, V.S. Saji and M.A. Quraishi, Corrosion Inhibitors for Acidizing Process in Oil and Gas Sectors, in Corrosion Inhibitors in the Oil and Gas Industry, Eds.: V.S. Saji and S.A. Umoren, Wiley-VCH Verlag GmbH \& Co. KGaA, Weinheim, Germany, 2020, 153-176. doi: 10.1002/9783527822140.ch6

4. M.A. Quraishi, D.S. Chauhan and V.S. Saji, Heterocyclic corrosion inhibitors for acid environments, in Heterocyclic Organic Corrosion Inhibitors, Eds.: M.A. Quraishi, D.S. Chauhan and V.S. Saji, Elsevier Inc., 2020, 87-131. doi: 10.1016/B978-0-12$\underline{818558-2.00004-7}$

5. Ya.G. Avdeev and Yu.I. Kuznetsov, Physicochemical aspects of inhibition of acid corrosion of metals by unsaturated organic compounds, Russ. Chem. Rev., 2012, 81, no. 12, 1133-1145. doi: 10.1070/RC2012v081n12ABEH004292

6. Ya.G. Avdeev, Nitrogen-containing six-membered heterocyclic compounds as corrosion inhibitors for metals in solutions of mineral acids - A review, Int. J. Corros. Scale Inhib., 2018, 7, no. 4, 460-497. doi: 10.17675/2305-6894-2018-7-4-1

7. Ya.G. Avdeev and Yu.I. Kuznetsov, Inhibitory protection of steels from hightemperature corrosion in acid solutions. A review. Part 1., Int. J. Corros. Scale Inhib., 2020, 9, no. 2, 394-426. doi: 10.17675/2305-6894-2020-9-2-2

8. S.A. Balezin, F.K. Kurbanov and N.I. Podobaev, Issledovanie zashchitnogo deistviya ingibitorov korrozii stali $\mathrm{v}$ solyanoi kislote $\mathrm{v}$ zavisimosti ot temperatury, davleniya $\mathrm{i}$ kontsentratsii (A study of the protective effect of steel corrosion inhibitors in hydrochloric acid depending on temperature, pressure and acid concentration), Zashch. Met. (Protection of metals), 1965, 1, no. 3, 337-340 (in Russian).

9. N.I. Podobayev, A.G. Voskresenskiy and G.F. Semikolenov, Izuchenie v kachestve ingibitorov korrozii nekotorykh atsetilenovykh soedinenii (A study of some acetylene compounds as corrosion inhibitors), in Ingibitory korrozii metallov (Metal corrosion inhibitors), Ed.: S.A. Balezin, Sudostroyeniye Publishing House, Moscow, 1965, $103-$ 114 (in Russian).

10. V.I. Rodionova, Kinetika rastvoreniya legirovannykh stalei $\mathrm{v}$ rastvorakh mineral'nykh kislot. Ingibirovanie protsessa (Kinetics of the dissolution of alloy steels in solutions of mineral acids. Inhibition of the process), in Ingibitory korrozii metallov (Metal corrosion inhibitors), Ed.: S.A. Balezin, Sudostroyeniye Publishing House, Moscow, 1965, 65-71 (in Russian). 
11. T.R. Melikyan, D.G. Rafaelyan, J.A. Kazaryan, S.S. Avagyan and K.Ts. Tagmazyan, Sintez i issledovanie ingibiruyushchikh svoistv chetvertichnykh ammonievykh solei, soderzhashchikh 2-khlor-4-fenoksi-2-butenil'nuyu gruppu (Synthesis and study of the inhibitory properties of quaternary ammonium salts containing a 2-chloro-4-phenoxy-2butenyl group), Armyanskiy khimicheskiy zhurnal (Chemical Journal of Armenia), 1985, 38, no. 11, 723-725 (in Russian).

12. F.A. Risha, N.K. Tagmazyan, G.P. Oganesyan and K.Ts. Tagmazyan, Sintez i issledovanie novykh polifunktsional'nykh chetvertichnykh ammonievykh solei $\mathrm{v}$ kachestve ingibitorov kislotnoi korrozii metallov (Synthesis and study of new polyfunctional quaternary ammonium salts as inhibitors of acid corrosion of metals), Khimicheskiy zhurnal Armenii (Chemical Journal of Armenia), 2007, 60, no. 5, 9991003 (in Russian).

13. G.P. Oganesyan and K.Ts. Tagmazyan, Khloristye (2,3-dikhlor-5-alkoksi-2penten)ilkhinolinii v kachestve ingibitorov kislotnoi korrozii ((2,3-Dichloro-5-alkoxy-2pentene)ylquinolinium chlorides as acid corrosion inhibitors), USSR Author's Certificate SU 1552597 A1, K. Marx Yerevan Polytechnic Institute, Application filing date: 09.01.1983, Published: 01.27.1996.

14. K.Ts. Tagmazyan and G.P. Oganesyan, Khloristye soli (3-khlor-5-alkoksi-2penten)ilkhinoliniya kak ingibitory kislotnoi korrozii ((3-Chloro-5-alkoxy-2penten)ylquinolinium chlorides as acid corrosion inhibitors), USSR Author's Certificate SU 1483883 A1, K. Marx Yerevan Polytechnic Institute, Application filing date: 31.07.1981, Published: 10.03.1996.

15. A.R. Sarda-Mantri and S.D. Wadekar, Use of berberine as corrosion inhibitor in well operations. WIPO Patent WO2016093807A1, International Filing Date 09.12.2014, International Publication Date 16.06.2016.

16. E.S. Ivanov, Ingibitory korrozii metallov v kislykh sredakh (Metal Corrosion Inhibitors in Acidic media), Metallurgiya, Moscow, 1986, 121 (in Russian).

17. N.L. Asatryan, G.P. Oganesyan and K.Ts. Tagmazyan, Sintez i issledovanie ingibiruyushchikh svoistv poliammonievykh solei, poluchennykh na osnove benzimidazola (Synthesis and study of the inhibitory properties of polyammonium salts derived from benzimidazole), Armyanskiy khimicheskiy zhurnal (Chemical Journal of Armenia), 1994, 47, no. 1-3, 64-65 (in Russian).

18. M.A. Quraishi, S. Ahmad and M.Q. Ansari, Inhibition of steel corrosion by some new triazole derivatives in boiling hydrochloric acid, Br. Corros. J., 1997, 32, no. 4, 297300 .

19. M.A. Quraishi and D. Jamal, Fatty Acid Triazoles: Novel Corrosion Inhibitors for Oil Well Steel (N-80) and Mild Steel, J. Am. Oil Chem. Soc., 2000, 77, no. 10, 1107-1111. doi: $10.1007 / \mathrm{s} 11746-000-0174-6$

20. M.A. Quraishi and D. Jamal, Corrosion inhibition by fatty acid oxadiazoles for oil well steel (N-80) and mild steel, Mater. Chem. Phys., 2001, 71, 202-205. doi: $\underline{10.1016 / \mathrm{S} 0254-0584(00) 00378-3}$ 
21. M.A. Quraishi, S. Ahmad and G. Venkatachari, Corrosion inhibition of mild steel in boiling hydrochloric acid by some thiazole derivatives, Bull. Electrochem., 2002, 18, no. 9, 399-402.

22. M.A. Quraishi and D. Jamal, CAHMT, A New and Eco-Friendly Acidizing Corrosion Inhibitor, Corrosion, 2000, 56, no. 2, 156-160. doi: 10.5006/1.3294388

23. N.I. Podobaev and Ya.G. Avdeev, A Review of Acetylene Compounds as Inhibitors of Acid Corrosion of Iron, Prot. Met., 2004, 40, no. 1, 7-13. doi: 10.1023/B:PROM.0000013105.48781.86

24. Ya.G. Avdeev, Protection of Steel in Solutions of Mineral Acids Using $\alpha, \beta$-Unsaturated Aldehydes, Ketones, and Azomethines, Prot. Met. Phys. Chem. Surf., 2015, 51, no. 7, 1140-1148. doi: 10.1134/S2070205115070023

25. V.I. Ivanskiy, Khimiya geterotsiklicheskikh soedinenii: Ucheb. posobie dlya universitetov (Chemistry of Heterocyclic Compounds: Manual for Universities), Vysshaya shkola, Moscow, 1978, 200-205 (in Russian).

26. G. Aromi, L.A. Barrios, O. Roubeau and P. Gamez, Triazoles and tetrazoles: Prime ligands to generate remarkable coordination materials, Coord. Chem. Rev., 2011, 255, 485-546. doi: 10.1016/j.ccr.2010.10.038

27. J.G. Haasnoot, Mononuclear, oligonuclear and polynuclear metal coordination compounds with 1,2,4-triazole derivatives as ligands, Coord. Chem. Rev., 2000, 200202, 131-185. doi: 10.1016/S0010-8545(00)00266-6

28. M. Rubio, R. Hernández, A. Nogales, A. Roig and D. López, Structure of a spincrossover $\mathrm{Fe}(\mathrm{II})-1,2,4$-triazole polymer complex dispersed in an isotactic polystyrene matrix, Eur. Polym. J., 2011, 47, no. 1, 52-60. doi: 10.1016/j.eurpolymj.2010.10.029

29. L.G. Lavrenova, E.V. Kirillova, V.N. Ikorskii, Yu.G. Shvedenkov, V.A. Varnek, L.A. Sheludyakova and S.V. Larionov, Iron(II) Complexes with 4-R-1,2,4-Triazoles (R = Ethyl, Propyl) Exhibiting ${ }^{1} \mathrm{~A}_{1} \rightleftarrows{ }^{5} \mathrm{~T}_{2}$ Spin Transition, Russ. J. Coord. Chem., 2001, 27, no. 1, 46-50. doi: 10.1023/A:1009540925335

30. M.B. Bushuev， L.G. Lavrenova, V.N. Ikorskii， Yu.G. Shvedenkov， V.A. Varnek, L.A. Sheludyakova and S.V. Larionov, Iron(II) Complexes with 4-R-1,2,4-Triazoles (R = Ethyl, Propyl, Isopropyl): Synthesis and Properties, Russ. J. Coord. Chem., 2004, 30, 284-290. doi: 10.1023/B:RUCO.0000022805.47477.75

31. T. Huxel, S. Riedel, J. Lach and J. Klingele, Iron(II) and Nickel(II) Complexes of NAlkylimidazoles and 1-Methyl-1H-1,2,4-Triazole: X-ray Studies, Magnetic Characterization, and DFT Calculations, Z. Anorg. Allg. Chem., 2012, 638, no. 6, 925934. doi: $10.1002 /$ zaac. 201200117

32. M.V. Tyurina, Ya.G. Avdeev, L.P. Kazanskii, A.Yu. Luchkin and O.A. Kireeva, Protection of Low-Carbon Steel from Corrosion in Hydrochloric Acid by 4-Substituted 1,2,4-Triazole, Prot. Met. Phys. Chem. Surf., 2016, 52, no. 7, 1147-1152. doi: $\underline{10.1134 / \mathrm{S} 2070205116070157}$ 
33. Ya.G. Avdeev, Yu.I. Kuznetsov and O.O. Zel', Zashchita ot korrozii nizkouglerodistoi stali v rastvorakh mineral'nykh kislot ingibitorom IFKhAN-94 (Corrosion protection of low-carbon steel in solutions of mineral acids by IFKhAN-94 inhibitor), Praktika protivokorrozionnoy zashchity (Practice of Corrosion Protection), 2011, no. 1, 8-13 (in Russian).

34. Ya.G. Avdeev, Yu.I. Kuznetsov and O.O. Zel', Novyi ingibitor kislotnoi korrozii stali IFKhAN-93 (New steel acid corrosion inhibitor - IFKhAN-93), Korroz.: Mater., Zashch. (Corrosion: Materials, Protection), 2010, no. 7, 12-17 (in Russian).

35. Ya.G. Avdeev, Yu.I. Kuznetsov, V.A. Ostrovskiy, M.V. Tyurina and P.A. Aleshunin, Zashchita nizkouglerodistoi stali $\mathrm{v}$ rastvorakh mineral'nykh kislot proizvodnymi tetrazola (Protection of low-carbon steel in mineral acid solutions by tetrazole derivatives), Korroz.: Mater., Zashch. (Corrosion: Materials, Protection), 2011, no. 4, 28-32 (in Russian).

36. Ya.G. Avdeev, A.Yu. Luchkin, Yu.I. Kuznetsov, I.G. Gorichev and M.V. Tyurina, Zashchita nizkouglerodistoi stali $\mathrm{v}$ solyanokislykh rastvorakh $\mathrm{v}$ usloviyakh vysokotemperaturnoi korrozii (do $160^{\circ} \mathrm{C}$ ) (Protection of low carbon steel in hydrochloric acid solutions from high temperature corrosion (up to $160^{\circ} \mathrm{C}$ )), Korroz.: Mater., Zashch. (Corrosion: Materials, Protection), 2011, no. 10, 26-31 (in Russian).

37. Ya.G. Avdeev, A.Yu. Luchkin, Yu.I. Kuznetsov, I.G. Gorichev and M.V. Tyurina, Zashchita nizkouglerodistoi stali $\mathrm{v}$ serno-kislykh rastvorakh ot vysokotemperaturnoi korrozii $\left(\right.$ do $200^{\circ} \mathrm{C}$ ) (Protection of low carbon steel in sulfuric acid solutions from high temperature corrosion (up to $\left.200^{\circ} \mathrm{C}\right)$ ), Korroz.: mater., zashch. (Corrosion: Materials, Protection), 2011, no. 8, 20-26 (in Russian).

38. Ya.G. Avdeev, P.A. Belinskii, Yu.I. Kuznetsov and O.O. Zel', High-Temperature Inhibitor of Steel Corrosion in Sulfuric Acid Solution, Prot. Met. Phys. Chem. Surf., 2010, 46, no. 7, 782-787. doi: 10.1134/S2070205110070087

39. M.A. Quraishi, Corrosion inhibitors for hot acid media, in Reviews on Corrosion Inhibitor Science and Technology, Eds.: A. Raman, P. Labine and M.A. Quraishi, USA, Houston, Texas: NACE International, 2004, 3, 17-1-17-21.

40. M.A. Quraishi and J. Rawat, Corrosion inhibiting action of tetramethyl-dithia-octaazacyclotetradeca-hexaene (MTAH) on corrosion of mild steel in hot $20 \%$ sulfuric acid, Mater. Chem. Phys., 2003, 77, 43-47. doi: 10.1016/S0254-0584(01)00576-4

41. Ya.G. Avdeev, D.S. Kuznetsov, M.V. Tyurina, A.Yu. Luchkin and M.A. Chekulaev, Protection of chromium-nickel steel in hydrochloric acid solution by a substituted triazole, Int. J. Corros. Scale Inhib., 2015, 4, no. 1, 1-14. doi: 10.17675/2305-68942015-4-1-001-014

42. Ya.G. Avdeev, D.S. Kuznetsov, M.V. Tyurina and M.A. Chekulaev, Protection of nickel-chromium steel in sulfuric acid solution by a substituted triazole, Int. J. Corros. Scale Inhib., 2015, 4, no. 2, 146-161. doi: 10.17675/2305-6894-2015-4-1-146-161 
43. Ya.G. Avdeev, L.V. Frolova, D.S. Kuznetsov, M.V. Tyurina and M.A. Chekulaev, Protection of stainless steel in hydrochloric acid solution containing hydrogen sulfide by inhibitors, Int. J. Corros. Scale Inhib., 2016, 5, no. 1, 87-99. doi: 10.17675/2305-68942016-5-1-7

44. Ya.G. Avdeev, L.V. Frolova, D.S. Kuznetsov, M.V. Tyurina and M.A. Chekulaev, Protection of stainless steel in sulfuric acid solution containing hydrogen sulfide by inhibitors, Int. J. Corros. Scale Inhib., 2016, 5, no. 2, 147-158. doi: 10.17675/23056894-2016-5-2-4

45. Ya.G. Avdeev, D.S. Kuznetsov, M.V. Tyurina, S.V. Oleynik and M.A. Chekulaev, High-temperature inhibitors of stainless steel corrosion in hydrochloric acid solutions, Int. J. Corros. Scale Inhib., 2017, 6, no. 2, 180-195. doi: 10.17675/2305-6894-2017-6$\frac{2-7}{Y a}$

46. Ya.G. Avdeev, D.S. Kuznetsov, M.V. Tyurina, S.V. Oleynik and M.A. Chekulaev, High-temperature inhibitors of stainless steel corrosion in sulfuric acid solutions, Int. J. Corros. Scale Inhib., 2017, 6, no. 1, 47-58. doi: 10.17675/2305-6894-2017-6-1-4

47. Ya.G. Avdeev, D.S. Kuznetsov and S.V. Oleinik, Inhibitor Protection of Steels in Solutions of Sulfuric Acid under High-Temperature Corrosion (up to $200^{\circ} \mathrm{C}$ ), Prot. Met. Phys. Chem. Surf., 2018, 54, no. 7, 1305-1311. doi: 10.1134/S2070205118070067

48. Ya.G. Avdeev, Protection of metals in phosphoric acid solutions by corrosion inhibitors. A review, Int. J. Corros. Scale Inhib., 2019, 8, no. 4, 760-798. doi: 10.17675/23056894-2019-8-4-1

49. A.A. Khadom and S.N. Farhan, Corrosion inhibition of steel in phosphoric acid, Corros. Rev., 2018, 36, no. 3, 267-280. doi: 10.1515/corrrev-2017-0104

50. M. El Faydy, B. Lakhrissi, C. Jama, A. Zarrouk, L.O. Olasunkanmi, E.E. Ebenso and F. Bentiss, Electrochemical, surface and computational studies on the inhibition performance of some newly synthesized 8-hydroxyquinoline derivatives containing benzimidazole moiety against the corrosion of carbon steel in phosphoric acid environment, J. Mater. Res. Technol., 2020, 9, no. 1, 727-748. doi: 10.1016/j.jmrt.2019.11.014

51. M. Boudalia, R.M. Fernández-Domene, M. Tabyaoui, A. Bellaouchou, A. Guenbour and J. García-Antón, Green approach to corrosion inhibition of stainless steel in phosphoric acid of Artemesia herba albamedium using plant extract, J. Mater. Res. Technol., 2019, 8, no. 6, 5763-5773. doi: 10.1016/j.jmrt.2019.09.045

52. M. Messali, H. Lgaz, R. Dassanayake, R. Salghi, S. Jodeh, N. Abidi and O. Hamed, Guar gum as efficient non-toxic inhibitor of carbon steel corrosion in phosphoric acid medium: Electrochemical, Surface, DFT and MD simulations studies, J. Mol. Struct., 2017, 1145, 43-54. doi: 10.1016/j.molstruc.2017.05.081

53. X. Li, S. Deng and H. Fu, Benzyltrimethylammonium iodide as a corrosion inhibitor for steel in phosphoric acid produced by dihydrate wet method process, Corros. Sci., 2011, 53, 664-670. doi: 10.1016/j.corsci.2010.10.013 
54. X. Li, S. Deng and H. Fu, Synergistic inhibition effect of 6-benzylaminopurine and iodide ion on the corrosion of cold rolled steel in $\mathrm{H}_{3} \mathrm{PO}_{4}$ solution, Corros. Sci., 2011, 53, 37043711. doi: $10.1016 /$ j.corsci.2011.07.016

55. H. Zarrok, A. Zarrouk, B. Hammouti, R. Salghi, C. Jama and F. Bentiss, Corrosion control of carbon steel in phosphoric acid by purpald - Weight loss, electrochemical and XPS studies, Corros. Sci., 2012, 64, 243-252. doi: 10.1016/j.corsci.2012.07.018

56. A.S. Yaro, A.A. Khadom and R.K. Wael, Apricot juice as green corrosion inhibitor of mild steel in phosphoric acid, Alexandria Eng. J., 2013, 52, 129-135. doi: 10.1016/j.aej.2012.11.001

57. M.A. Ameer and A.M. Fekry, Corrosion inhibition of mild steel by natural product compound, Prog. Org. Coat., 2011, 71, 343-349. doi: 10.1016/j.porgcoat.2011.04.001

58. A. Ghanbari, M.M. Attar and M. Mahdavian, Corrosion inhibition performance of three imidazole derivatives on mild steel in 1 M phosphoric acid, Mater. Chem. Phys., 2010, 124, no. 2-3, 1205-1209. doi: 10.1016/j.matchemphys.2010.08.058

59. A. Zarrouk, H. Zarrok, R. Salghi, B. Hammouti, F. Bentiss, R. Touir and M. Bouachrine, Evaluation of N-containing organic compound as corrosion inhibitor for carbon steel in phosphoric acid, J. Mater. Environ. Sci., 2013, 4, no. 2, 177-192.

60. Ya.G. Avdeev, M.V. Tyurina and Yu.I. Kuznetsov, Protection of low-carbon steel in phosphoric acid solutions by mixtures of a substituted triazole with sulfur-containing compounds, Int. J. Corros. Scale Inhib., 2014, 3, no. 4, 246-253. doi: 10.17675/23056894-2014-3-4-246-253

61. M. Thirumalaikumar and S. Jegannathan, Inhibition Effects of Nitrones on the Corrosion of Mild Steel in Organic Acid Media, Port. Electrochim. Acta, 2011, 29, no. 1, 1-8. doi: 10.4152/pea.201101001

62. M.A. Quraishi and H.K. Sharma, Inhibition of mild steel corrosion in formic and acetic acid solutions, Indian J. Chem. Technol., 2004, 11, no. 3, 331-336.

63. M.A. Quraishi and H.K. Sharma, Heterocyclic anils as corrosion inhibitors of mild steel in formic and acetic acid solutions, Indian J. Chem. Technol., 2005, 12, no. 1, 98-104.

64. F.A. Ansari and M.A. Quraishi, Oleo-chemicals Triazoles as Effective Corrosion Inhibitors for Mild Steel in Acetic Acid Media, PetroMin PipeLiner, 2010, Jan-Mar, $36-42$.

65. S. Deng, X. Li and G. Du, Two ditetrazole derivatives as effective inhibitors for the corrosion of steel in $\mathrm{CH}_{3} \mathrm{COOH}$ solution, J. Mater. Res. Technol., 2019, 8, no. 1, 13891399. doi: $10.1016 / j . j m r t .2018 .09 .010$

66. S. Khan, M.Z.A. Rafiquee, N. Saxena and M.A. Quraishi, Inhibition of carbon steel corrosion by azathione derivatives in organic acid solutions, Anti-Corros. Methods Mater., 2009, 56, no. 3, 145-153. doi: 10.1108/00035590910955504

67. M.Z.A. Rafiquee, S. Khan, N. Saxena and M.A. Quraishi, Influence of Some Thiadiazole Derivatives on Corrosion Inhibition of Mild Steel in Formic and Acetic Acid Media, Port. Electrochim. Acta, 2007, 25, 419-434. doi: 10.4152/pea.200704419 
68. F.A. Ansari and M.A. Quraishi, Inhibitive Effect of Some Gemini Surfactants as Corrosion Inhibitors for Mild Steel in Acetic Acid Media, Arabian J. Sci. Eng., 2011, 36, 11-20. doi: $10.1007 / \mathrm{s} 13369-010-0008-6$

69. F.A. Ansari and M.A. Quraishi, Inhibitive Performance of Gemini Surfactants as Corrosion Inhibitors for Mild Steel in Formic Acid, Port. Electrochim. Acta, 2010, 28, no. 5, 321-335. doi: 10.4152/pea.201005321

70. M.A. Quraishi, F.A. Ansari and D. Jamal, Thiourea derivatives as corrosion inhibitors for mild steel in formic acid, Mater. Chem. and Phys., 2003, 77, 687-690. doi: 10.1016/S0254-0584(02)00130-X

71. M.A. Quraishi and F.A. Ansari, Corrosion inhibition by fatty acid triazoles for mild steel in formic acid, J. Appl. Electrochem., 2003, 33, 233-238. doi: 10.1023/A:1024106123577

72. M.A. Quraishi and F.A. Ansari, Fatty acid oxadiazoles as corrosion inhibitors for mild steel in formic acid, J. Appl. Electrochem., 2006, 36, 309-314. doi: 10.1007/s10800$\underline{005-9065-\mathrm{Z}}$

73. M. Mobin and S. Masroor, Alkanediyl- $\alpha, \omega-b i s$ (dimethylcetylammonium bromide) gemini surfactants as novel corrosion inhibitors for mild steel in formic acid, Mater. Res., 15, no. 6, 837-847. doi: 10.1590/S1516-14392012005000112

74. M.A. Quraishi and F.A. Ansari, Inhibitive effect of FA derivatives on mild steel corrosion in the presence of formic acid, J. Am. Oil Chem. Soc., 2003, 80, 705-710. doi: 10.1007/s11746-003-0761-6

75. Ya.G. Avdeev, Yu.I. Kuznetsov and M.V. Tyurina, Ob ingibirovanii korrozii nizkouglerodistoi stali v goryachikh rastvorakh organicheskikh kislot (On the Inhibition of Mild Steel Corrosion in Hot Organic Acid Solutions), Korroz.: Mater., Zashch. (Corrosion: Materials, Protection), 2012, no. 3, 24-28 (in Russian).

76. D. Yang, S.H. Liu, Y.P. Shao, S.D. Xu, L.L.Zhao, Q.Q. Lia and H.H. Ge, Electrochemical and XPS studies of alkyl imidazoline on the corrosion inhibition of carbon steel in citric acid solution, Corros. Rev., 2016, 34, no. 5-6, 1-11. doi: 10.1515/corrrev-2016-0016

77. X. Li, S. Deng, X. Xie and H. Fu, Inhibition effect of bamboo leaves' extract on steel and zinc in citric acid solution, Corros. Sci., 2014, 87, 15-26. doi: 10.1016/j.corsci.2014.05.013

78. Ya. Avdeev, M. Tyurina, V. Rabinkov and A. Luchkin, Inhibitive Protection of LowCarbon Steel in Citric Acid Solutions, in MATEC Web of Conferences, RSP 2017 XXVI R-S-P Seminar 2017, Theoretical Foundation of Civil Engineering, 2017, 117, Article Number 00143. doi: 10.1051/matecconf/201711700143

79. S.A. Umoren and M.M. Solomon, Effect of halide ions on the corrosion inhibition efficiency of different organic species - A review, J. Ind. Eng. Chem., 2015, 21, 81100. doi: $10.1016 /$ j.jiec.2014.09.033 
80. Ya.G. Avdeev, A.V. Panova, T.E. Andreeva and Yu.I. Kuznetsov, Vliyanie solei Fe(III) na zashchitu stalei v rastvorakh mineral'nykh kislot ingibitorami korrozii (The effect of $\mathrm{Fe}$ (III) salts on the protection of steels in solutions of mineral acids by corrosion inhibitors), Korroz.: Mater., Zashch. (Corrosion: Materials, Protection), 2019, no. 11, 32-40 (in Russian). doi: 10.31044/1813-7016-2019-0-11-32-40

81. Ya.G. Avdeev, O.A. Kireeva, D.S. Kuznetsov and Yu.I. Kuznetsov, The Influence of Hexamethylenetetramine on the Corrosion Inhibition of Low Carbon Steel in Mixtures of Sulfurous and Phosphorus Acids Containing Fe(III) by IFKhAN-92 and KNCS Composition, Prot. Met. Phys. Chem. Surf., 2018, 54, no. 7, 1298-1304. doi: $\underline{10.1134 / \mathrm{S} 2070205118070055}$

82. Ya.G. Avdeev, O.A. Kireeva, D.S. Kuznetsov and Yu.I. Kuznetsov, Usilenie urotropinom ingibirovaniya korrozii stali 08PS kompozitsiei IFKhAN-92 s KNCS v smesyakh NSl i $\mathrm{H}_{3} \mathrm{PO}_{4}$, soderzhashchikh $\mathrm{Fe}(\mathrm{III})$ (Improvement of corrosion inhibition of steel 08PS by composition of IFKhAN-92 with KNCS in mixtures of $\mathrm{HCl}$ and $\mathrm{H}_{3} \mathrm{PO}_{4}$ containing Fe(III) by urotropine), Korroz.: Mater., Zashch. (Corrosion: Materials, Protection), 2018, no. 7, 22-28 (in Russian). doi: 10.31044/1813-7016-2018-0-7-22-28

83. A.Yu. Luchkin, Fiziko-khimicheskie aspekty zashchity stali ot kislotnoi korrozii proizvodnymi triazola pri povyshennykh temperaturakh (Physicochemical aspects of steel protection against acid corrosion by triazole derivatives at elevated temperatures), Dissertatsiya kandidata khimicheskikh nauk (PhD Chemistry Dissertation), Moscow State Pedagogical University, A.N. Frumkin Institute of Physical Chemistry and Electrochemistry, RAS, Moscow, 2013, 127 pp. (in Russian).

84. N.I. Podobayev and V.I. Kotov, K voprosu o mekhanizme zashchitnogo deistviya atsetilenovykh soedinenii pri korrozii stali $\mathrm{v}$ solyanoi kislote (To the question of the protective mechanism of acetylene compounds during corrosion of steel in hydrochloric acid), in Uchenyye zapiski №340 (Scientific notes No. 340), Moscow, MGPI im. V.I. Lenina, 1971, 15-26 (in Russian).

85. N.I. Podobayev, V.I. Kotov and A.G. Voskresensky, O khimicheskom prevrashchenii dimetiletinilkarbinola pri korrozii stali v solyanoi kislote (On the chemical conversion of dimethylethinylcarbinol during corrosion of steel in hydrochloric acid), in Uchenyye zapiski №340 (Scientific notes No. 340), Moscow, MGPI im. V.I. Lenina, 1971, 27-31 (in Russian).

86. E. Ituen, O. Akaranta and A. James, Corrosion inhibition characteristics of 2-[(E)-[5methoxy-1-[4-(trifluoromethyl)phenyl]pentylidene]amino]oxyethanamine on steel in simulated oilfield acidizing solution, J. King Saud Univ., Eng. Sci., 2019, 31, 191-199. doi: $10.1016 /$ j.jksues.2017.07.002

87. W. Zhang, H.-J. Li, M. Wang, L.-J. Wang, Q. Pan, X. Ji, Y. Qin and Y.-C. Wu, Tetrahydroacridines as corrosion inhibitor for X80 steel corrosion in simulated acidic oilfield water, J. Mol. Liq., 2019, 293, 111478. doi: 10.1016/j.molliq.2019.111478 
88. R. Salim, E. Ech-chihbi, H. Oudda, F. El Hajjaji, M. Taleb and S. Jodeh, A Review on the Assessment of Imidazo[1,2-a]pyridines As Corrosion Inhibitor of Metals, J. BioTribo-Corros., 2019, 5, 14. doi: 10.1007/s40735-018-0207-3

89. I.B. Obot, E.E. Ebenso and M.M. Kabanda, Metronidazole as environmentally safe corrosion inhibitor for mild steel in $0.5 \mathrm{M} \mathrm{HCl}$ : Experimental and theoretical investigation, J. Environ. Chem. Eng., 2013, 1, no. 3, 431-439. doi: 10.1016/j.jece.2013.06.007

90. M. Rbaa and B. Lakhrissi, Novel oxazole and imidazole based on 8-hydroxyquinoline as a corrosion inhibition of mild steel in $\mathrm{HCl}$ solution: Insights from experimental and computational studies, Surf. Interfaces, 2019, 15, 43-59. doi: 10.1016/j.surfin.2019.01.010

91. V. Srivastava, J. Haque, C. Verma, P. Singh, H. Lgaz, R. Salghi and M.A. Quraishi, Amino acid based imidazolium zwitterions as novel and green corrosion inhibitors for mild steel: Experimental, DFT and MD studies, J. Mol. Liq., 2017, 244, 340-352. doi: 10.1016/j.molliq.2017.08.049

92. M. Ouakki, M. Galai, M. Rbaa, A.S. Abousalem, B. Lakhrissi, E.H. Rifi and M. Cherkaoui, Quantum chemical and experimental evaluation of the inhibitory action of two imidazole derivatives on mild steel corrosion in sulphuric acid medium, Heliyon, 2019, 5, e02759. doi: 10.1016/j.heliyon.2019.e02759

93. N.V. Likhanova, M.A. Dominguez-Aguilar, O. Olivares-Xometl, N. Nava-Entzana, E. Arce and H. Dorantes, The effect of ionic liquids with imidazolium and pyridinium cations on the corrosion inhibition of mild steel in acidic environment, Corros. Sci., 2010, 52, 2088-2097. doi: 10.1016/j.corsci.2010.02.030

94. L.-G. Qiu, A.-J. Xie and Y.-H. Shen, A novel triazole-based cationic gemini surfactant: synthesis and effect on corrosion inhibition of carbon steel in hydrochloric acid, Mater. Chem. Phys., 2005, 91, 269-273. doi: 10.1016/j.matchemphys.2004.11.022

95. F. Bentiss, M. Bouanis, B. Mernari, M. Traisnel, H. Vezin and M. Lagrenee, Understanding the adsorption of $4 \mathrm{H}-1,2,4$-triazole derivatives on mild steel surface in molar hydrochloric acid, Appl. Surf. Sci., 2007, 253, 3696-3704. doi: 10.1016/j.apsusc.2006.08.001

96. M. Tourabi, K. Nohair, M. Traisnel, C. Jama and F. Bentiss, Electrochemical and XPS studies of the corrosion inhibition of carbon steel in hydrochloric acid pickling solutions by 3,5-bis(2-thienylmethyl)-4-amino-1,2,4-triazole, Corros. Sci., 2013, 75, 123-133. doi: $10.1016 / \mathrm{j}$. corsci.2013.05.023

97. M. El Belghiti, Y. Karzazi, A. Dafali, B. Hammouti, F. Bentiss, I.B. Obot, I. Bahadur and E.E. Ebenso, Experimental, quantum chemical and Monte Carlo simulation studies of 3,5-disubstituted-4-amino-1,2,4-triazoles as corrosion inhibitors on mild steel in acidic medium, J. Mol. Liq., 2016, 218, 281-293. doi: 10.1016/j.molliq.2016.01.076 
98. M.E. Belghiti, Y. Karzazi, A. Dafali, I.B. Obot, E.E. Ebenso, K.M. Emran, I. Bahadur, B. Hammouti and F. Bentiss, Anti-corrosive properties of 4-amino-3,5bis(disubstituted)-1,2,4-triazole derivatives on mild steel corrosion in $2 \mathrm{M} \mathrm{H}_{3} \mathrm{PO}_{4}$ solution: Experimental and theoretical studies, J. Mol. Liq., 2016, 216, 874-886. doi: 10.1016/j.molliq.2015.12.093

99. C. Verma, M.A. Quraishi and A. Singh, 5-Substituted 1H-tetrazoles as effective corrosion inhibitors for mildsteel in $1 \mathrm{M}$ hydrochloric acid, J. Taibah Univ. Sci., 2016, 10, 718-733. doi: $\underline{10.1016 / j . j t u s c i .2015 .10 .005}$

100. S. Deng, X. Li and H. Fu, Nitrotetrazolium blue chloride as a novel corrosion inhibitor of steel in sulfuric acid solution, Corros. Sci., 2010, 52, 3840-3846. doi: 10.1016/j.corsci.2010.07.020

101. X. Li, S. Deng and H. Fu, Blue tetrazolium as a novel corrosion inhibitor for cold rolled steel in sulfuric acid solution, Mater. Chem. Phys., 2011, 129, 696-700. doi: 10.1016/j.matchemphys.2011.05.042

102. Ya.G. Avdeev, A.Yu. Luchkin and Yu.I. Kuznetsov, Adsorption of IFKhAN-92 Corrosion Inhibitor on Low Carbon Steel from Hydrochloric Acid Solution, Prot. Met. Phys. Chem. Surf., 2013, 49, no. 7, 865-868. doi: 10.1134/S2070205113070046

103. Ya.G. Avdeev, A.Yu. Luchkin and Yu.I. Kuznetsov, Adsorbtsiya ingibitora korrozii IFKhAN-92 na nizkouglerodistoi stali iz sernokislogo rastvora (Adsorption of corrosion inhibitor IFKhAN-92 on low-carbon steel from sulphuric acid solution), Korroz.: Mater., Zashch. (Corrosion: Materials, Protection), 2019, no. 9, 1-5 (in Russian). doi: 10.31044/1813-7016-2019-0-9-1-5

104. Ya.G. Avdeev, A.Yu. Luchkin, M.V. Tyurina and Yu.I. Kuznetsov, Adsorption of IFKhAN-92 Corrosion Inhibitor From Acidic Phosphate Solution on Low Carbon Steel, Prot. Met. Phys. Chem. Surf., 2017, 53, no. 7, 1247-1251. doi: 10.1134/S2070205117070048

105. Ya.G. Avdeev, D.S. Kuznetsov and Yu.I. Kuznetsov, Adsorbtsiya ingibitora korrozii IFKhAN-92 na khromonikelevoi stali iz rastvorov mineral'nykh kislot (Adsorption of corrosion inhibitor IFKhAN-92 on chromium-nickel steel from mineral acid solutions), Korroz.: Mater., Zashch. (Corrosion: Materials, Protection), 2020, no. 2, 27-32 (in Russian). doi: 10.31044/1813-7016-2020-0-2-27-32

106. N.P. Andreeva, D.S. Kuznetsov and Ya.G. Avdeev, Study of the Adsorption of the IFKhAN-92 Inhibitor on the Surface of Chromium-Nickel Steel from Hydrochloric and Sulfuric Acid Solutions by Ellipsometry, Prot. Met. Phys. Chem. Surf., 2019, 55, no. 7, 1280-1286. doi: $10.1134 /$ S2070205119070025

107. S. Zhang, Z. Tao, W. Li and B. Hou, The effect of some triazole derivatives as inhibitors for the corrosion of mild steel in $1 \mathrm{M}$ hydrochloric acid, Appl. Surf. Sci., 2009, 255, 6757-6763. doi: 10.1016/j.apsusc.2008.09.089

108. A.Y. Musa, A.A.H. Kadhum, A.B. Mohamad and M.S. Takriff, Experimental and theoretical study on the inhibition performance of triazole compounds for mild steel corrosion, Corros. Sci., 2010, 52, 3331-3340. doi: 10.1016/j.corsci.2010.06.002 
109. Q. Deng, H.-W. Shi, N.-N. Ding, B.-Q. Chen, X.-P. He, G. Liu, Y. Tang, Y.-T. Long and G.-R. Chen, Novel triazolyl bis-amino acid derivatives readily synthesized via click chemistry as potential corrosion inhibitors for mild steel in $\mathrm{HCl}$, Corros. Sci., 2012, 57, 220-227. doi: 10.1016/i.corsci.2011.12.014

110. D.M. Gurudatt, K.N. Mohana and H.C. Tandon, Synthesis of new 1,2,4-triazole derivatives and their anticorrosion properties on mild steel in hydrochloric acid medium, J. Mol. Liq., 2015, 211, 275-287. doi: 10.1016/j.molliq.2015.07.014

111. T.K. Chaitra, K.N.S. Mohana and H.C. Tandon, Thermodynamic, electrochemical and quantum chemical evaluation of some triazole Schiff bases as mild steel corrosion inhibitors in acid media, J. Mol. Liq., 2015, 211, 1026-1038. doi: 10.1016/j.molliq.2015.08.031

112. H. Rahmani, K.I. Alaoui, M. El Azzouzi, F. Benhiba, A. El Hallaoui, Z. Rais, M. Taleb, A. Saady, B. Labriti, A. Aouniti and A. Zarrouk, Corrosion assessement of mild steel in acid environment using novel triazole derivative as a anti-corrosion agent: A combined experimental and quantum chemical study, Chem. Data Collect., 2019, 24, 100302. doi: 10.1016/j.cdc.2019.100302

113. Z. Rouifi, F. Benhiba, M. El Faydy, T. Laabaissi, H. About, H. Oudda, I. Warad, A. Guenbour, B. Lakhrissi and A. Zarrouk, Performance and computational studies of new soluble triazole as corrosion inhibitor for carbon steel in $\mathrm{HCl}$, Chem. Data Collect., 2019, 22, 100242. doi: $10.1016 /$ j.cdc.2019.100242

114. G. Gece, The use of quantum chemical methods in corrosion inhibitor studies, Corros. Sci., 2008, 50, 2981-2992. doi: 10.1016/j.corsci.2008.08.043

115. Ya.G. Avdeev, A.Yu. Luchkin, Yu.I. Kuznetsov, L.P. Kazanskii and Yu.E. Pronin, Zashchitnoe posledeistvie ingibitora IFKhAN-92 pri korrozii stali v solyano- i sernokislykh sredakh (The protective aftereffect of the inhibitor IFKhAN-92 for steel corrosion in hydrochloric and sulphuric acid solutions), Korroz.: Mater., Zashch. (Corrosion: Materials, Protection), 2012, no. 11, 20-25 (in Russian).

116. Ya.G. Avdeev, M.V. Tyurina, Yu.I. Kuznetsov, Yu.E. Pronin and L.P. Kazanskii, Zashchita nizkouglerodistoi stali $\mathrm{v}$ rastvorakh fosfornoi kisloty ingibitorom IFKhAN92. Ch. 2 (Protection of low-carbon steel in solutions of phosphoric acid by inhibitor IFKhAN-92. Part 2), Korroz.: Mater., Zashch.(Corrosion: Materials, Protection), 2013, no. 6, 17-23 (in Russian).

117. Ya.G. Avdeev, Yu.B. Makarichev, D.S. Kuznetsov and L.P. Kazanskii, Osobennosti zashchity khromonikelevoi stali $\mathrm{v}$ rastvorakh solyanoi kisloty proizvodnym triazola (Specificity of protection of chromium-nickel steel in hydrochloric acid solutions by triazole derivative), Korroz.: Mater., Zashch. (Corrosion: Materials, Protection), 2018, no. 9, 22-29 (in Russian). doi: 10.31044/1813-7016-2018-0-9-22-29 
118. Ya.G. Avdeev, Yu.B. Makarichev, D.S. Kuznetsov and L.P. Kazanskii, Zashchitnoe posledeistvie ingibitora IFKhAN-92 pri korrozii khromonikelevoi stali v solyanoi kislote (Protective aftereffect of IFKhAN-92 inhibitor for chromium-nickel stainless steel corrosion in hydrochloric acid), Korroz.: Mater., Zashch. (Corrosion: Materials, Protection), 2019, no. 4, 20-25 (in Russian). doi: 10.31044/1813-7016-2019-0-4-20-25

119. Ya.G. Avdeev, Yu.B. Makarichev, D.S. Kuznetsov and L.P. Kazanskii, Osobennosti zashchity khromonikelevoi stali $\mathrm{v}$ rastvorakh sernoi kisloty proizvodnym triazola (Protective aftereffect of IFKhAN-92 inhibitor for chromium-nickel stainless steel corrosion in sulfuric acid), Korroz.: Mater., Zashch. (Corrosion: Materials, Protection), 2019, no. 1, 15-21 (in Russian). doi: 10.31044/1813-7016-2019-0-1-15-21

120. A. Espinoza-Vázquez, G.E. Negrón-Silva, R. González-Olvera, D. Angeles-Beltrán, H. Herrera-Hernández, M. Romero-Romo and M. Palomar-Pardavé, Mild steel corrosion inhibition in $\mathrm{HCl}$ by di-alkyl and di-1,2,3-triazole derivatives of uracil and thymine, Mater. Chem. Phys., 2014, 145, no. 3, 407-417. doi: 10.1016/j.matchemphys.2014.02.029

121. F. Bentiss, C. Jama, B. Mernari, H. El Attari, L. El Kadi, M. Lebrini, M. Traisnel and M. Lagrenee, Corrosion control of mild steel using 3,5-bis(4-methoxyphenyl)-4-amino1,2,4-triazole in normal hydrochloric acid medium, Corros. Sci., 2009, 51, 1628-1635. doi: $10.1016 /$ j.corsci.2009.04.009

122. Q. Deng, N.-N. Ding, X.-L. Wei, L. Cai, X.-P. He, Y.-T. Long, G.-R. Chen and $\mathrm{K}$. Chen, Identification of diverse 1,2,3-triazole-connected benzyl glycosideserine/threonine conjugates as potent corrosion inhibitors for mild steel in $\mathrm{HCl}$, Corros. Sci., 2012, 64, 64-73. doi: 10.1016/j.corsci.2012.07.001

123. C.M. Fernandes, L.X. Alvarez, N. Escarpini dos Santos, A.C. Maldonado Barrios and E. Ariel Ponzio, Green synthesis of 1-benzyl-4-phenyl-1H-1,2,3-triazole, its application as corrosion inhibitor for mild steel in acidic medium and new approach of classical electrochemical analyses, Corros. Sci., 2019, 149, 185-194. doi: 10.1016/j.corsci.2019.01.019

124. H.H. Hassan, E. Abdelghani and M.A. Amin, Inhibition of mild steel corrosion in hydrochloric acid solution by triazole derivatives. Part I. Polarization and EIS studies, Electrochim. Acta, 2007, 52, 6359-6366. doi: 10.1016/j.electacta.2007.04.046

125. H.H. Hassan, Inhibition of mild steel corrosion in hydrochloric acid solution by triazole derivatives. Part II: Time and temperature effects and thermodynamic treatments, Electrochim. Acta, 2007, 53, 1722-1730. doi: 10.1016/j.electacta.2007.08.021

126. M. Lebrini, M. Traisnel, M. Lagrenee, B. Mernari and F. Bentiss, Inhibitive properties, adsorption and a theoretical study of 3,5-bis(n-pyridyl)-4-amino-1,2,4-triazoles as corrosion inhibitors for mild steel in perchloric acid, Corros. Sci., 2008, 50, 473-479. doi: $10.1016 / j . c o r s c i .2007 .05 .031$ 
127. W. Li, Q. He, C. Pei and B. Hou, Experimental and theoretical investigation of the adsorption behaviour of new triazole derivatives as inhibitors for mild steel corrosion in acid media, Electrochim. Acta, 2007, 52, 6386-6394. doi: 10.1016/j.electacta.2007.04.077

128. F. Xu, J. Duan, S. Zhang and B. Hou, The inhibition of mild steel corrosion in $1 \mathrm{M}$ hydrochloric acid solutions by triazole derivative, Mater. Lett., 2008, 62, 4072-4074. doi: $10.1016 /$ j.matlet.2008.05.037

129. H.-L. Wang, R.-B. Liu and J. Xin, Inhibiting effects of some mercapto-triazole derivatives on the corrosion of mild steel in $1.0 \mathrm{M} \mathrm{HCl}$ medium, Corros. Sci., 2004, 46, 2455-2466. doi: 10.1016/j.corsci.2004.01.023

130. Ya.G. Avdeev and A.Yu. Luchkin, Effect of IFKhAN-92 inhibitor on electrode reactions and corrosion of mild steels in hydrochloric and sulfuric acid solutions, Int. J. Corros. Scale Inhib., 2013, 2, no. 1, 53-66. doi: 10.17675/2305-6894-2013-2-1-053-066

131. Ya.G. Avdeev and M.V. Tyurina, Vliyanie ingibitora IFKhAN-92 na elektrodnye reaktsii i korroziyu nizkouglerodistoi stali $\mathrm{v}$ rastvore fosfornoi kisloty (Effect of IFKhAN-92 on electrode reactions and corrosion of low-carbon steel in phosphoric acid solution), Korroz.: Mater., Zashch. (Corrosion: Materials, Protection), 2015, no. 6, 1925 (in Russian).

132. E.V. Filimonov, G.A. Ayuyan, A.I. Shcherbakov and T.A. Pisarenko, Korrozionnye i elektrokhimicheskie svoistva stali Kh18N10T v fosfornokislykh rastvorakh pri vysokoi temperature (Corrosion and electrochemical properties of Kh18N10T steel in phosphate solutions at high temperature), Zashch. Met., 1999, 35, no. 6, 656-659 (in Russian).

133. E.V. Filimonov, Vliyanie ionov okislitel'nogo tipa na ustoichivost' passivnogo sostoyaniya stali Kh18N10T $v$ rastvorakh fosfornoi kisloty (The effect of oxidizing ions on the stability of the passive state of Kh18N10T steel in phosphoric acid solutions), Dissertatsiya kandidata khimicheskikh nauk (PhD Chemistry Dissertation), Institute of Physical Chemistry RAS, Moscow, 2004, 186 pp. (in Russian).

134. E.V. Filimonov and A.I. Shcherbakov, Inhibiting the corrosion of stainless steel in phosphoric acid, Prot. Met., 2000, 36, no. 3, 296-298. doi: 10.1007/BF02758411

135. E.V. Filimonov and A.I. Shcherbakov, The Effect of Products of Nitrate Ion Reduction on the Kinetics of Electrode Reactions on Stainless Steel, Prot. Met., 2001, 37, no. 6, 539-542. doi: 10.1023/A:1012859312143

136. E.V. Filimonov and A.I. Shcherbakov, On the Effect of Copper and Nitrate Ions on the Stainless Steel Corrosion in Phosphoric Acid, Prot. Met., 2002, 38, 95-96. doi: 10.1023/A:1013821321734

137. E.V. Filimonov and A.I. Shcherbakov, Catalytic Effect of Copper Ions on Nitrate Reduction, Prot. Met., 2004, 40, 280-285. doi: 10.1023/B:PROM.0000028923.12984.8c 